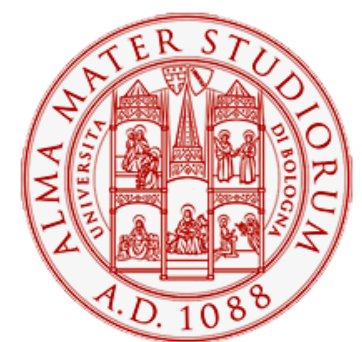

Alma Mater Studiorum - Università di Bologna DEPARTMENT OF ECONOMICS

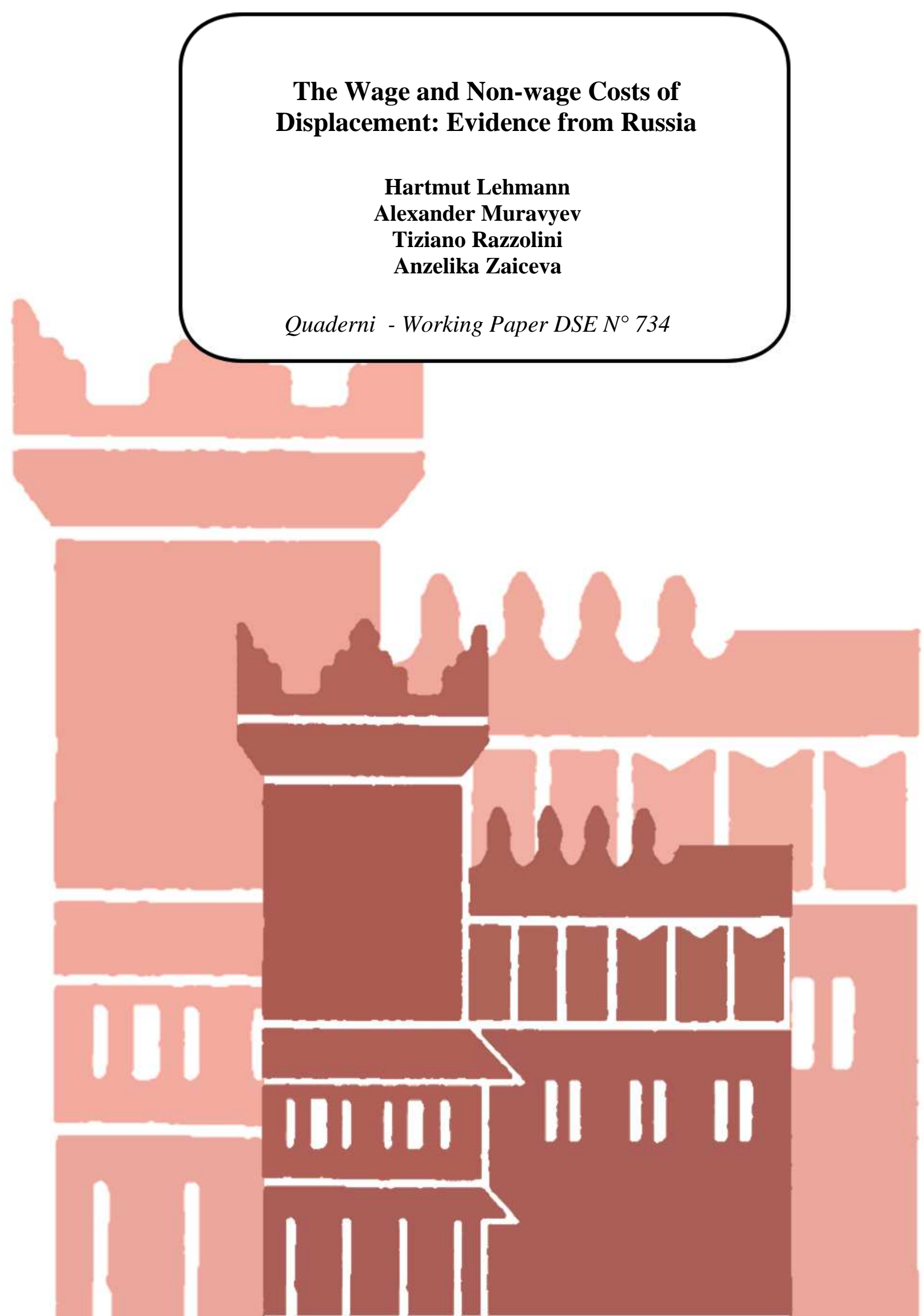




\title{
The Wage and Non-wage Costs of Displacement: Evidence from Russia*
}

\author{
Hartmut Lehmann* (University of Bologna and IZA) \\ Alexander Muravyev (IZA) \\ Tiziano Razzolini (University of Siena) \\ Anzelika Zaiceva (University of Modena and Reggio Emilia and IZA)
}

This version: March 2011

\begin{abstract}
This paper is the first to analyze the costs of job loss in Russia, using unique new data from the Russian Longitudinal Monitoring Survey over the years 2003-2008, including a special supplement on displacement that was initiated by us. We employ fixed effects regression models and propensity score matching techniques in order to establish the causal effect of displacement for displaced individuals. The paper is innovative insofar as we investigate fringe and in-kind benefits and the propensity to have an informal employment relationship as well as a permanent contract as relevant labor market outcomes upon displacement. We also analyze monthly earnings, hourly wages, employment and hours worked, which are traditionally investigated in the literature. Compared to the control group of non-displaced workers (i.e. stayers and quitters), displaced individuals face a significant income loss following displacement, which is mainly due to the reduction in employment and hours worked. This effect is robust to the definition of displacement. The losses seem to be more pronounced and are especially large for older workers with labor market experience and human capital acquired in Soviet times and for workers with primary and secondary education. Workers displaced from state firms experience particularly large relative losses in the short run, while such losses for workers laid off from private firms are more persistent. Turning to the additional non-conventional labor market outcomes, there is a loss in terms of the number of fringe and in-kind benefits for reemployed individuals but not in terms of their value. There is also some evidence of an increased probability of working in informal jobs if displaced. These results point towards the importance of both firm-specific human capital and of obsolete skills obtained under the centrally planned economy as well as to a wider occurrence of job insecurity among displaced workers.
\end{abstract}

Keywords: Costs of job loss, worker displacement, propensity score matching, Russia.

JEL classification: J64, J65, P50.

\footnotetext{
* We are grateful to John Bonin, Daniel Hamermesh and participants of an ACES session at the ASSA meetings in Denver 2011 and of seminars at IZA, Bonn and the University of Bologna for comments and suggestions. Lehmann and Muravyev are grateful to the Volkswagen Foundation for financial support within the project "The political economy of labor market reform in transition economies: a comparative perspective.” We would also like to thank Vladimir Gimpelson, Rostislav Kapeliushnikov, Mikhail Kosolapov and Polina Kozyreva for their invaluable help in developing the RLMS displacement supplement.

* Corresponding author: hartmut.lehmann@unibo.it.
} 


\section{The Wage and Non-wage Costs of Displacement: Evidence from Russia}

\section{Introduction}

In recent years there has been a resurgence of interest in the fate of displaced workers in developed economies. This interest has been further heightened by the effects of the world financial crisis on the U.S. labor market where displacement at the national level in 2009 has occurred to an extent not experienced in the last two decades (U.S.BLS 2010). In most OECD countries the costs of job loss are large for displaced workers, but these costs differ in their nature when we compare the U.S. with Continental European countries. In the U.S. labor market where the phenomenon has been studied in great detail using various data sets, these costs are long-term even for displaced workers who find reemployment, with relative wage losses estimated to lie between 7 and 35 percent even several years after finding a new job (see Couch and Placzek 2010, Table 1). Most studies on displacement in Continental Europe do not find large relative wage losses for displaced workers who have found re-employment; instead the main costs of job loss consist in foregone earnings due to periods of non-employment (see, e.g., Kuhn 2002 and Hijzen et al. 2010). ${ }^{1}$

The consequences of job loss in transition countries have received very scant attention in the literature on labor markets in transition countries in spite of large restructuring and labor reallocation during the first decade of transition (Djankov and Murell 2002). This can be mainly explained by a lack of appropriate data. Rigorous studies on worker displacement in transition economies can be counted on one hand. Lehmann, Philips and Wadsworth (2005) and Lehmann, Pignatti and Wadsworth (2006) discuss the incidence and the costs of worker displacement in Estonia and Ukraine. In

\footnotetext{
${ }^{1}$ In the U.S. labor market, the costs of job loss are not limited to wage losses and foregone income due to non-employment spells. For example, Sullivan and von Wachter (2009) establish that displacement at age 40 will shorten life expectancy of an average worker by 1.0 to 1.5 years.
} 
both studies, the authors find no relative wage losses of re-employed displaced workers, but establish large foregone earnings for a majority of workers experiencing very long non-employment spells. In contrast, the study by Orazem, Vodopivec and Wu (2005) on Slovenia finds lasting relative wage losses of re-employed displaced workers.

This is the first paper on the costs of job loss in Russia. Our study attempts to isolate the causal effect of displacement on labor market outcomes in Russia, using fixed effects regression and propensity score matching models. This analysis has become possible thanks to the development of a supplement on displacement, which was developed by us and administered on our behalf to the $17^{\text {th }}$ round of the Russian Longitudinal Monitoring Survey (RLMS) in 2008. The collected supplementary data in conjunction with the main body of the RLMS panel data provide a unique data base with which the effects of worker displacement in the Russian labor market can be rigorously investigated. The main contribution of our paper to the general literature consists in looking at three additional labor market outcomes that thus far have found little attention by researchers when comparing the labor market experience of displaced and nondisplaced workers, namely fringe and in-kind benefits, the likelihood of having an informal job and the probability of having a permanent contract.

Our study covers the years 2003 to 2008, when the initial transition from a centrally planned to a market-oriented economy is over, which makes the Russian labor market quite comparable to labor markets in developed economies. Hence, our analysis provides an additional interesting data point to the empirical evidence on the costs of job loss in OECD economies. These years are also a period of relentless growth of the 
Russian economy (see table A1). ${ }^{2}$ We, therefore, investigate whether even during this booming period job loss was an important phenomenon in the Russian labor market and which costs were associated with worker displacement and how these costs were distributed across the workforce. As far as conventional wage costs are concerned, we are interested to establish whether the costs consist predominantly in foregone earnings due to long spells of non-employment or whether re-employed displaced workers bear lasting relative wage losses. These contrasting scenarios have different policy implications. If the main costs of job loss are related to long non-employment spells, government policies that improve job search of displaced workers seem imperative. If, on the other hand, upon re-employment workers experience relative wage losses in a persistent fashion, retraining and further training schemes seem to be an appropriate response.

The non-wage costs that we analyze point to non-conventional labor market outcomes that might be of interest to policy makers. If displacement is associated with a higher likelihood of taking up informal employment and with a lower incidence of the receipt of fringe benefits, then this has important implications for social policy

The next section presents those features of the Russian system of industrial relations that have an impact on the incidence and the costs of displacement as well as on the search efforts of displaced workers. This is followed in section 3 by a discussion of the data and a descriptive analysis of worker displacement in Russia. In section 4 we outline our research strategy, followed by the presentation of the main results in section 5. Finally, robustness checks are discussed in the penultimate section, while in section 7 we draw some conclusions.

\footnotetext{
${ }^{2}$ In this period the GDP growth rate oscillated between 6 and 8 percent. Also, the world financial crisis had no major impact on the Russian labor market in 2008 as inspection of the wage and unemployment data in Table A1 attest.
} 


\section{Pertinent features of the Russian system of industrial relations}

The Russian system of industrial relations has mostly taken shape during the first decade of transition to a market economy following the collapse of the Soviet Union in 1991. Prior to 1991, most of the country's productive assets were controlled by the state while trade unions (characterized by almost universal membership) were an integral part of the Communist party/state apparatus at all levels, transmitting policy directives of the CPSU to the workforce (Borisov and Clarke 2006). In the early 1990s, Russia's reformist government created a legislative framework for a tripartite dialogue, with tripartite commissions introduced at the federal and regional levels and annual agreements between government, employers, and trade unions negotiated at the level of enterprises, regions, and the country as a whole.

According to formal criteria, by the mid-1990s Russia had an established system of industrial relations, characterized by a high unionization rate, multi-level collective bargaining, a high coverage rate, and a very high degree of coordination among both employees and employers (Cazes 2002). More recent and more careful examinations of the country's industrial relations system, however, have revealed that many of the institutions created in the 1990s remained more like an empty framework, that is, a form without content. In particular, decisions of the tripartite commission have no legislative status under Russian law and are therefore not binding; general agreements concluded usually contain many purely declarative provisions, and violations of these agreements are typically left without sanctions. The government often violates the principle of transparency in decision-making as well as the principle of giving equal weight to the three parties involved (Borisov 2001), including some recent steps to marginalize trade unions (Borisov and Clarke 2006). Employers’ organizations are often week to serve as a counterpart of trade unions and tend to use their seat in tripartite commissions as yet 
another channel to lobby the government. The largest organization of trade unions in the country - The Federation of Independent Trade Unions of Russia (FNPR) - has not been particularly effective in protecting workers' interests, and the role of alternative trade unions remains limited (Borisov 2001). Perhaps, the most revealing indicator of the unstable and immature nature of the existing system of industrial relations in Russia is a dramatic decline in the unionization rate. According to Russian Public Opinion Research Center, by 2008 trade union membership rate was only 24\%, which is close to a four-fold decrease in the course of two decades following the collapse of communism (Nezavisimaya gazeta 16.10.2008). ${ }^{3}$

The general vagueness and the lack of enforcement of collective agreements ${ }^{4}$ leave regulations provided in Russia's labor law a major role in the country's system of industrial relations. Until very recently, a widely held belief was that Russia had very rigid - by international comparisons - employment protection legislation (EPL), including immense firing costs for employers. For example, Denisova and Svedberg (2007) state that "The Russian Labor Code will remain restrictive compared to those in OECD countries even in its new revised version.” Similarly, Gimpelson, Kapeliushnikov, and Lukyanova (2010) argue that "Whatever of the existing indices we choose, they confirm that the Russian EPL, as written in the law, is among the most stringent in the

\footnotetext{
${ }^{3}$ Union density is usually regarded as the most important among the factors influencing wage setting and labor relations in general (Eichhorst, Feil, and Braun 2008).

${ }^{4}$ The vast gap between what is on paper and reality is well summarized by Venn (2009): “...collective bargaining in Russia ostensibly occurs at several different levels, but often there is little real bargaining (e.g. agreements are made between trade unions and the government without involving employers). National-level bargaining typically comprises general statements of intent and little real content relating to wages or working conditions. Sectoral agreements often just replicate legislative standards, while the content of regional-level agreements varies widely. Company-level agreements are often not adhered to or enforced. Sectoral agreements can be extended by the Minister of Labour if they cover a majority of employees in a particular sector, but uncovered employers can opt out of the extension by writing to the Minister within 30 days of the extension.”
} 
world."5 However, recent estimates by OECD (2009) show that Russia’s labor law is not particularly restrictive even on the books. The OECD EPL score for Russia is just 1.9, which is well below the EU average. Of the three components of the overall EPL index, Russia only scores high in terms of protection of permanent contracts. The regulations regarding fixed-term employment relationships are rather liberal and, what is particularly relevant in our context, the regulations pertaining to protection against collective dismissals are not rigid.

Specifically, Russia’s Labor Code stipulates that criteria of mass dismissal are to be defined in industrial and (or) territorial agreements. Additional regulations typically apply from 50 dismissals upwards (Resolution of Government No. 99 of 05.02.1993). In the case of mass dismissals, the employer has to inform the labor administration and the trade union in writing three months in advance (compared with two months in the case of an individual dismissal). Employers are held to pay severance pay, which cannot exceed 3 monthly wages, but have no obligations to provide extra compensation or finance retraining of dismissed workers. Russia's Law on employment of 1991 allowed local governments to postpone collective dismissals for up to 6 months (with full or partial compensation of the employer's costs) in case they were fraught with severe social consequences, but this provision was eliminated in 2004 (see also Muravyev 2010 for details about the evolution of Russia’s EPL).

Another important aspect directly related to the fate of displaced workers concerns preemptive rights to retain jobs in case of redundancy dismissals. According to Article 178 of Russia’s Labor Code, employers are obliged, when making decisions about redundancy firings, to retain workers with higher productivity and higher qualification.

\footnotetext{
${ }^{5}$ Nevertheless, these and other researchers admit that when imperfect enforcement of law is accounted for, the level of rigidity is lower: while formally rather restrictive, Russia's law regarding employment protection is effectively rather flexible.
} 
This provision, which has existed since 1971, can generate negative selection of workers and thus result in particularly bad labor market outcomes for displaced workers observed in the post-displacement period.

Unemployment benefits in Russia, as in all other successor states of the former USSR, are very non-generous as far as the replacement rate is concerned (Lehmann and Muravyev 2010). While the benefits are directly related to past wages of fired workers, there is an upper cap effectively restricting them to a very low level. In particular, the maximum monthly benefit amounted to 2880 RUR in 2005 and 4900 RUR in 2009, which corresponded to $33.7 \%$ and $28.3 \%$ of the average wage in the two years, respectively.

One important aspect of industrial relations in Russia worth commenting on concerns workers' participation in corporate governance. It is well-known that privatization of the 1990s resulted in substantial employee ownership (often majority stakes in companies’ equity) in major sectors of Russia’s industry, providing employees with a potential channel to influence employment policies via election and representation in corporate boards (e.g., Hare and Muravyev 2003). However, there is evidence that these rights were rarely used by workers (Filatotchev, Wright, and Bleaney, 1999). Moreover, since the end of the mass privatization program in 1994, employee ownership has declined dramatically. According to Dolgopiatova (2007), in the middle of the last decade workers and trade union representatives typically occupied less than $8 \%$ of seats in corporate boards. We therefore believe that the influence of workers and trade unions on wage and employment policies of firms through corporate governance channels is minor if not negligible at all during the period of our analysis. 
All in all, the described system of industrial relations and of income support for the unemployed leads one to moot that neither the former nor the latter attenuate the costs of job loss in Russia and that workers experiencing redundancy or plant closure are pretty much left to their own devices when confronted with such an adverse labor market event.

\section{Data and descriptive analysis}

The analysis uses a database that consists of the panel data of the Russian Longitudinal Monitoring Survey (RLMS) for the years 2003 to 2008 and a special supplement on displacement that was administered on our behalf to the $17^{\text {th }}$ round of the RLMS between October and December 2008. ${ }^{6}$ The main RLMS data form a well known rich panel data set, which has provided the empirical basis of innumerable papers on the Russian labor market. We use the main panel data of the years 2003 to 2008 and combine them with the new data from the supplement that cover the years 2003 to 2008 and that allow the reconstruction of a complete labor market history of each respondent of working age for the indicated period. This unique new data base allows us to analyze the costs of job loss in Russia for the first time in a rigorous fashion.

The supplement provides retrospective information on respondents' job and nonemployment spells over the years 2003 to 2008. We have information on the beginning and the end of each job spell and of each non-employment spell. Vital for our analysis is, of course, information on the reason for separating from a job. The possible answers given in the supplement are reproduced in table A2 and are very much standard in labor force surveys administered in OECD countries. As respondents are told to only give one answer it is relatively straightforward to classify job separations into quits and

\footnotetext{
${ }^{6}$ Throughout its history, the data of the main RLMS data set have been collected in the months of October to December.
} 
displacements. ${ }^{7}$ Answers 1 through 5 in table A2 are undisputedly related to involuntary job loss while answers 6 and 7 infrequently might involve individual dismissals connected to improper behavior requiring disciplinary action. In our main analysis we classify answers 1 through 7 as involuntary job loss; we also perform robustness checks where we tighten the definition of displacement by dropping respondents giving answer 6 or 7 and find no substantial differences to our main analysis. ${ }^{8}$

We also have information on the actual weekly hours worked, on occupation and the sector of employment as well as on the wage at the beginning and the end of each job. For those with non-employment who are on the unemployment register we also have benefits at the beginning and the end of the registered unemployment spell. In addition, and this is particularly relevant for our analysis, we have wages and premia net of taxes as well as actual weekly hours worked in March, June, September and December of each year over the period 2003 to 2008.

We are also interested in the question how displacement affects the number and expected value of fringe and in-kind benefits. Respondents are asked to tick from a list of 11 benefits in the supplement, giving the benefits they receive at the beginning and at the end of each job. By far the most important benefits are paid holidays (recipients are 87 percent of the sample of controls and treated), sick pay (86 percent) and maternity/paternity benefits (72 percent). These are all fringe benefits, while in-kind benefits are, for example, medical treatment in enterprise-owned polyclinics or sanatoria as well as kindergarten services within the enterprise. The answers in these cases, however, also allow money transfers to workers for payment of these services in external institutions. So, these benefits are in a sense a mixture of in-kind and fringe benefits.

\footnotetext{
${ }^{7}$ For a discussion of the pros and cons of using survey data to define displacement see the introductory chapter in Kuhn (2002).

${ }^{8}$ Answers 6 and 7 comprise $16 \%$ of the displaced sample.
} 
They are at any rate of less importance since only 16, 19 and 4 percent of the sample receive them. Since multiple answers are allowed we can establish the number of benefits as a labor market outcome. We also exercise care in calculating the expected value of each benefit. ${ }^{9}$ We thus can analyze whether displacement has an impact on the number and value of fringe and in-kind benefits for those workers who find re-employment.

A second interesting labor market outcome related to displacement, which has been ignored in the literature, is informal employment. In this analysis we employ the legalistic definition of informal employment, i.e. we define informal employment as the absence of social security contributions that by law should be paid by employers and employees (cf. World Bank 2007). In the case of our supplement, we proxy informal employment if the respondent points to an oral employment agreement between him or her and the employer.

A main concern with retrospective data is, of course, recall bias, which might be especially severe in the case of earnings data. Since the main RLMS questionnaire asks for wages of the month previous to the reference week, we can compare wages in the main RLMS data set given by respondents who are interviewed in the month of October in each year to wages in September in the supplement in each year. We thus can calculate the difference of these two wages in each year for these individuals. Both wages are net of taxes but the wage in the main data set excludes premia. Hence we would expect that the mean of the differences in the two wages is negative, which is indeed the case. What is important, though, is whether this negative difference is correlated with the treatment, i.e. displacement. We, therefore, perform a simple regression of the difference on a

\footnotetext{
${ }^{9}$ These calculations that are quite cumbersome are not shown here but available upon request.
} 
displacement dummy and establish that the coefficient on this dummy is insignificant. ${ }^{10}$ We take this as an encouraging sign and conclude that any potential measurement error of monthly earnings due to recall bias seems to be orthogonal to our treatment variable.

We have merged the supplement data with the main RLMS data for the waves 2003 to 2008. This allows us to add demographic and household characteristics, educational attainment and region of residence at annual frequencies. Table 1 gives descriptive statistics of the variables for the non-displaced and the displaced in 2003 that are used in the fixed effects regressions and the propensity score matching procedures.

We start our descriptive analysis of worker displacement in Russia with the presentation of annual quit and displacement rates for the years 2003 to 2008 . We see in the upper panel of figure 1 that many workers quit in this boom period and that quit rates are a multiple of displacement rates. However, the displacement rate is not negligible, reaching more than 3 percent in several years, which in comparison with mature capitalist economies is at the lower end of but, nevertheless, within the range of displacement rates (Kuhn 2002). How do the Russian displacement rates compare to layoff numbers in other transition economies? The Russian are of the same magnitude as the displacement rates found in Slovenia in the early years of transition (Orazem et al. 2005) and somewhat lower than those found in Ukraine (Lehmann et al. 2006). In Estonia displacement rates were very high in early transition, reaching 13 percent in 1992 and coming down to around 6 percent at the end of the decade. The Estonian economy was, however, shedding labor in a very aggressive fashion at the beginning of the transition, leading to excessively high job loss rates in international perspective (Lehmann et al. 2005). So,

\footnotetext{
${ }^{10}$ Using 21,804 observations, the estimated equation gives: Diff=-614.25( $\left.\mathrm{t}=15.37\right)-131.07 *$ displacement $(\mathrm{t}=-1.06)$. It shows that the mean difference is indeed negative and, given the large number of observations and the low t-statistic on the displacement dummy, that there is no systematic difference between the mean difference of the non-displaced and the mean difference of the displaced.
} 
displacement is an important phenomenon in the Russian labor market even in years when the economy booms, affecting ca. 2 million workers per year. Plant or firm closures are responsible only for a minor part of displacements; the dominant reason for job loss is clearly redundancies as the bottom panel of figure 1 demonstrates. ${ }^{11}$

Are displaced workers systematically different from non-displaced workers? Inspection of the columns of non-displaced and displaced workers in table 1 allows us to infer that the latter are more likely to be female, have less tenure, be less educated, be less skilled, work in smaller and privately owned firms, be employed in construction, trade and consumer services and agriculture, and receive somewhat lower wages. These unconditional results are confirmed by multinomial regressions where the origin state is employment and remaining employed, being displaced and quitting are the three destination states. ${ }^{12}$

How rapidly do displaced workers return to work? To answer this question we calculate cumulative return rates to employment, conditional on non-employment duration, for the years 2003 to $2008 .^{13}$ In Russia, around 50\% of displaced workers return to full-time work within the first three months after displacement while one-third of the workers returns within one month of displacement. At least half of all those who return to work within six months do so during the first month. These job moves within one month can be considered job-to-job moves. Kuhn (2002) finds similar results for displaced workers in the U.S.; two-thirds of them are re-employed within six months. In Britain, half of the displaced workers return within two months. In Russia, it takes a year for two

\footnotetext{
${ }^{11}$ The small number of displaced due to plant or firm closure implies that we cannot investigate the effects of displacement for this sub-group separately.

${ }^{12}$ To save space we do not show the MNL results; they are, however, available upon request.

${ }^{13}$ These rates are based on the complement of the Kaplan-Meier estimator of survivor functions in nonemployment (Smith 2002). The results are only discussed here and not presented. However, they are available upon request.
} 
thirds of the displaced to find re-employment, leading to relatively modest levels of longterm non-employment. ${ }^{14}$ Lehmann et al. (2005) find a similar picture in the case of Estonian displaced workers in the 1990s, with between 53 and 65 percent gaining reemployment within 6 months. Since Estonia has been considered one of the most dynamic economies in the 1990s among transition countries, this seems to indicate that the Russian labor market has become quite dynamic in the growth period of 2003 to 2008, capable of absorbing the majority of displaced workers within a year.

Even if most displaced workers are reabsorbed by the Russian labor market within a year after job loss, we know from the literature that independent of the state of the economy displacement does impose large costs on workers who are separated from their jobs involuntarily. We now turn to a rigorous evaluation of these costs.

\section{Research strategy}

The fixed effect regressions that we perform are very much standard in the displacement literature and of the following type:

$$
y_{i t}=\alpha_{i}+\eta_{t} Q_{t}+X_{i t} \beta+\sum_{j=-4}^{j=16} D I S_{i t}^{j} \delta_{j}+\varepsilon_{i t}
$$

where $y_{i t}$ is labor market outcome for individual $\mathrm{i}$ at time $\mathrm{t}$ and an element of the set \{monthly earnings, employment rate, hours worked, hourly wage, number of benefits, value of benefits, Prob(oral contract) and Prob(permanent written contract)\}. To take account of unobserved time-invariant factors impacting on $y_{i t}$ that are potentially

\footnotetext{
14 We do not distinguish between unemployment and inactivity here for two reasons. First, the number of observations of displaced workers is small which makes it difficult to find reliable estimates for the two separate labor market states. Second, given the non-generous unemployment benefit systems in Russia, it is difficult for most workers to maintain themselves and their families entirely with the help of unemployment benefits. This leads to fluid borders between the states of unemployment and inactivity. Hence, it is better to treat the two states as one.
} 
heterogeneous across individuals we include the individual-specific fixed effect $\alpha_{i}$. $Q_{t}$ is a set of quarterly time dummies, while $X_{i t}$ contains the set of covariates shown in table 1 . Ever since the seminal job loss study of Jacobson, Lalonde and Sullivan (1993) who found earnings losses of displaced workers even before the displacement occurred, researchers have entered a lag-and-lead structure of displacement dummies. Our dummy $D I S_{i t}^{j}$ is set equal to 1 for quarter $\mathrm{j}$ if worker i was displaced at time t. In our specification, the coefficient $\delta_{j}$ captures the effect of displacement on the outcome variable up to four quarters before job loss took place $(\mathrm{j}=-4)$, during the quarter when displacement occurred $(\mathrm{j}=0)$ as well as up to 16 quarters after the event $(\mathrm{j}=16)$. Finally, $\varepsilon_{i t}$ is a white noise error term. In the case that unobserved heterogenous factors are exclusively time-invariant the displacement effects are identified with our fixed effects regression model through the coefficients $\delta_{j}$. However, when some of the unobserved factors vary over time, the coefficients $\delta_{j}$ are no longer consistently estimated and our analysis needs to employ a different approach.

When evaluating the costs of worker i's displacement we essentially ask the question that is posed in the evaluation literature: What is the outcome (e.g., monthly earnings, employment status etc.) of worker i who is treated (here: displaced) relative to the hypothetical outcome that would have prevailed if the same worker had not been treated (displaced)? Since the treated worker can never be observed in the non-treatment state the problem arises how to construct a credible counterfactual. When the treatment is randomized, under certain assumptions it is sufficient to compare the average outcome of the treated ( $\left.E\left(Y_{i}(1) \mid D_{i}=1\right)\right)$ and the average outcome of the control group (i.e. the non- 
treated) $E\left(Y_{i}(0) \mid D_{i}=0\right)$. The difference in these two average outcomes will identify the average treatment effect of the treated (ATT):

$$
A T T=E\left(Y_{i}(1) \mid D_{i}=1\right)-E\left(Y_{i}(0) \mid D_{i}=1\right) \quad(2),
$$

where $E\left(Y_{i}(0) \mid D_{i}=1\right)$ is the counterfactual average outcome, i.e. the average outcome of the treated in the non-treatment state. With randomized experiments, if we do not encounter "randomization and substitution biases" (Heckman and Smith 1996),

$$
E\left(Y_{i}(0) \mid D_{i}=1\right)=E\left(Y_{i}(0) \mid D_{i}=0\right),
$$

i.e. the average outcome of the non-treated is a consistent estimate of the counterfactual $E\left(Y_{i}(0) \mid D_{i}=1\right)$.

Alas, displacement is never a randomized treatment and we need to employ those techniques of the evaluation literature that are applied to observational data (see, e.g., Heckman, Lalonde and Smith 1999). Essentially these techniques try to get $E\left(Y_{i}(0) \mid D_{i}=0\right)$ as close as possible to the counterfactual $E\left(Y_{i}(0) \mid D_{i}=1\right)$. In this study, we employ the propensity score matching procedure proposed by Rosenbaum and Rubin (1983). For identification of a causal treatment effect they invoke the conditional independence assumption (CIA): conditional on workers' pre-treatment characteristics, the potential outcome in the non-treatment scenario is independent of the treatment status, i.e.

$$
E\left(Y_{i}(0) \mid D_{i}=1, P(X)\right)=E\left(Y_{i}(0) \mid D_{i}=0, P(X)\right)
$$

where $D_{i}$ is the treatment variable that takes the value 1 under treatment and the value 0 if the individual is in the non-treatment state, while $Y_{i}(0)$ is the outcome variable for 
individual $\mathrm{i}$ in the non-treatment state. $P(X)$ is the propensity score, estimated with the probit model:

$$
P(X)=\operatorname{Pr}(D=1 \mid X) \quad(4)
$$

Matching takes place on the propensity score using the nearest neighbor method.

Workers who in March 2004 are between 15 and 59 years of age and who have at least one year of tenure enter our sample. ${ }^{15}$ As controls we take those who remain in their jobs (stayers) and those who quit (quitters). ${ }^{16}$ Our final sample consists of 3097 individuals, 443 of whom are identified as displaced using the classification of table A2. The covariates presented in table 1 are used for our propensity score matching procedure. All variables are lagged one year, so we match on the propensity score estimated with the covariate values of March 2003. Table 1 also shows for the overall sample that balancing is achieved with virtually all covariates.

At an intuitive level, propensity score matching attempts to balance the unobserved characteristics of two samples by balancing the observed characteristics. This works particularly well when the number of covariates is large and includes those variables that are potentially correlated with the outcome variable of interest in an exhaustive fashion. Given the large number of such variables shown in table 1 we are pretty sure that we balance the unobserved characteristics with our matching procedure. Balancing of the observed characteristics is achieved with all samples that we use in our analysis. We are thus confident to identify the causal effect of displacement in quarter $\mathrm{j}$ by the difference in the average outcome in quarter $\mathrm{j}$ of those displaced at time $\mathrm{t}$ and the average outcome of the controls in quarter $\mathrm{j}$ :

\footnotetext{
${ }^{15}$ With the first condition we focus on the core workforce and can ignore retirement issues, while the second condition ensures that we look only at workers who have relatively stable employment relationships. We also require that there is no missing information.

${ }^{16}$ The recent literature selects both stayers and quitters as controls, since choosing only stayers as controls might lead to an upward bias of displacement effects.
} 


$$
\Delta_{j}=E\left(Y_{i t}^{j}(1) \mid D_{i}=1, P\left(X_{2003}\right)\right)-E\left(Y_{i t}^{j}(0) \mid D_{i}=0, P\left(X_{2003}\right)\right)
$$

$\mathrm{j}=-4, . ., 0, \ldots .16$. Analytical standard errors are calculated using the algorithm developed by Lechner (2001).

\section{Empirical findings}

We first present the labor market outcomes that are standard in the literature for all individuals as well as for all re-employed. Column 1 of table 2 lists the four quarters before displacement, the quarter when displacement occurs (bef_d_0) and the sixteen quarters after job loss. For the four standard outcomes we report the coefficients $\delta_{j}$ of the fixed effects regressions and the differences between mean outcomes of the treated and mean outcomes of the controls, $\Delta_{j}$, with the controls being determined by our propensity score matching routine. The results of the two estimation techniques are quite similar for all four outcomes even though the displacement effects based on the propensity score matching are somewhat larger. In the discussion that follows we focus on these latter results.

In the pre-displacement period monthly earnings ${ }^{17}$ are not significantly lower for the displaced, a scenario that is contrary to the findings of, e.g., the earnings profiles in the U.S. labor market (see, e.g., Jacobson et al. 1993) but often found in the literature on displacement in European countries. Monthly earnings drop dramatically in the quarter of displacement and reach their lowest level in the first two quarters after job loss. These earnings losses are large as they amount to roughly 35 percent of the average wage (11700 Rubles for the controls in the quarter of displacement). They are attenuated with

\footnotetext{
${ }^{17}$ As a first approximation, we follow the literature in imputing zero earnings for the unemployed. Later on, we perform robustness checks where we take into account the level of unemployment benefits when estimating losses in monthly earnings.
} 
time but still amount to approximately 26 percent of the average wage two years after job loss (8 quarters after job loss the average wage of controls has grown to roughly 12750 Rubles); only after three years do the monthly earnings losses become statistically insignificant. The second earnings outcome is the hourly wage, which has a similar profile over time as monthly earnings. In the four quarters before job loss the hourly wage of the displaced does not differ from that of the non-displaced, while in the quarter of displacement we have a huge loss amounting to roughly 50 percent of the average hourly wage (about 63 Rubles). This loss is reduced to around a quarter of the average hourly wage within two years (when the average hourly wage of controls amounts to 69 Rubles) and disappears completely after three years.

These very large losses in monthly earnings and the hourly wage come about because of a substantial reduction in weekly hours worked and because of large falls in the employment rates of displaced workers. One year after job loss displaced workers work on average nearly 10 hours per week less than their non-displaced counterparts. This deficit in hours worked remains throughout the reported period and amounts to around 6 hours even 4 years after workers were displaced. With the onset of job loss the average employment rate falls by 44 percentage points ${ }^{18}$, i.e. we see a large inflow into non-employment. Within a year the gap between the employment rate of the nondisplaced and the displaced falls to 25 percentage points and remains around 20 percentage points for the rest of the reported period.

The last four columns of table 2 present the results for the hourly wage of those displaced workers who found re-employment. We look at all re-employed and at the

\footnotetext{
${ }^{18}$ Since before displacement both controls and displaced have a 100 percent employment rate, a fall of 44 percentage points amounts to a 44 percent fall.
} 
subset of those who switched industry. We investigate the latter group to see whether the loss of industry-specific human capital has a negative impact on wages of re-employed displaced workers, a finding established by Neal (1995) for the United States. The results for all re-employed show no relative wage losses as they are found in the U.S. labor market (Couch and Placzek 2010). These findings for Russia are in line with the evidence for several European countries, though. For those displaced workers who upon reemployment switch industry we essentially also find no evidence of a relative wage loss. So, in times of strong economic growth of the Russian economy loss of industry-specific human capital does not seem to affect wages of re-employed displaced workers.

The evidence presented in table 2 for the whole sample is clear cut. The main costs of job loss in the Russian labor market are foregone earnings due to spells of nonemployment and reduced hours worked. At the same time, re-employed displaced workers are not penalized by earning lower wages than their non-displaced counterparts.

In the descriptive section, we established that the incidence of displacement is not evenly distributed across workers. In addition, empirical findings in the literature point to the fact that the costs of job loss are not evenly spread over the set of displaced workers. For example, Ichino et al. (2007) find lower employment rates for older displaced workers in Austria immediately following job loss; these older workers, however, catch up with their younger counterparts in the longer term. Kletzer and Fairlie (2003) establish that in the U.S. labor market young displaced workers have shorter-lived earnings losses than the main group of displaced workers. Schwerdt et al. (2010) find earnings losses that are larger and more persistent for white-collar workers, relating this finding to the importance of firm-specific human capital. 
In a first stab at the data we, therefore, take account of this potential heterogeneity in outcomes by investigating the displacement effects with respect to monthly earnings, the hourly wage, the employment rate and the hourly wage upon re-employment for various subsets of the displaced. We splice the data by gender, by previous employment in a state vs. private firm, by age and by educational attainment. When it comes to age we divide the sample into those individuals who were younger than 18 years of age in 1991 and those who were older than or equal to 18 years, since we are interested to see whether potentially obsolete skills acquired under the Soviet regime have an impact on the labor market outcomes of the displaced. In the case of educational attainment we compare displaced workers with tertiary education (high education) to those with secondary education or less (low education).

Figure 2 presents the outcomes dividing the displacement sample by gender. The results using the propensity score matching procedure are presented together with 95 percent confidence intervals. ${ }^{19}$ Monthly earnings do not differ much by gender even if in absolute terms losses for males are somewhat higher than for their female counterparts. In relative terms these losses are close to each other since female earnings are substantially lower than male earnings. There is some difference as far as the persistence of earnings losses are concerned: males reach the same level of earnings as the non-displaced approximately within two years while in the case of females it takes an additional year to eliminate earnings losses. The same pattern can be observed with hourly wages. Displaced women have a slightly steeper fall in the employment rate upon job loss but over the long term their employment rates recover faster than those of their male

\footnotetext{
${ }^{19}$ These confidence intervals are based on the analytical standard errors developed by Lechner (2001).
} 
counterparts. Finally, neither men nor women experience any relative wage losses upon re-employment.

Throughout the reported period after occurred job loss, displaced workers who previously worked in private firms have larger monthly earnings losses in absolute terms than displaced workers with previous employment in state firms (first panel of figure 3). However, in relative terms the picture is more complex. The average monthly earnings of the workers not displaced form state firms remain roughly constant between quarters 0 and 16, hovering around 7500 Rubles, while the average monthly earnings of the workers not displaced from private firms grow from around 14000 Rubles in quarter 0 to around 19000 Rubles in quarter 15. So, relative earnings losses for those displaced from state firms are larger than such losses for those displaced from private firms in the short term. For example, in quarters 1 and 2 absolute losses of 3243 and 2948 Rubles for the former group translate into relative losses of 41 and 37 percent respectively. In contrast, the absolute losses in these quarters for those displaced from private firms, 4342 and 4517 Rubles, amount to 31 and 30 percent respectively. In the longer term, however, those displaced from state-owned firms incur smaller losses whether measured in absolute or relative terms, since after the $6^{\text {th }}$ quarter earnings losses do not exist or are no longer significant for this group while they remain significant for those displaced from private firms throughout the rest of the observed quarters. The hourly wage profiles shown in the second panel of figure 3 are very similar to those of monthly earnings. There are at least two explanations why workers displaced from state firms have less persistent earnings and wage losses than those workers displaced from private firms. First, some of the workers with previous employment in state firms are eventually hired by private firms where wages are on average higher and grow. Consequently initial earnings losses are 
relatively rapidly recovered. Second, the fact that average earnings and wages grow in private firms might be an indication of the importance of firm-specific human capital in these firms. Hence, workers who are displaced from private firms might incur these persistent earnings and wage losses because of a large loss of firm-specific human capital that workers displaced from state firms do not incur. Upon job loss the fall in the employment rate is much larger for workers from state firms and remains below the employment rate of workers from private firms for 6 quarters. So, also on this measure the losses of workers displaced from private firms are more persistent. For the reemployed of both sub-groups there are no relative wage losses throughout the entire period.

We next compare the labor market outcomes of the cohort that acquired most of its human capital under central planning (workers older than 18 years in 1991) and of the cohort with human capital acquisition in the transition period (workers younger or equal to 18 years in 1991). ${ }^{20}$ Monthly earnings losses are very different across the two samples. The cohort with "old" human capital has large and persistent monthly earnings losses while for the cohort with "new" human capital these losses are short-lived: two quarters after displacement earnings losses become insignificant for the latter group while they persist nearly three years for the group with "old” human capital. In contrast, persistent hourly wage losses can also be observed for the cohort with "new" human capital, remaining statistically significant for nine quarters after job loss. The cohort with the "old” capital experiences these losses for 11 quarters. Monthly earnings losses are large and so persistent for the group with the "old" capital in particular because the

\footnotetext{
${ }^{20}$ We cannot distinguish these cohort effects from age effects, though. In an earlier version of the paper, we have experimented also with disaggregating by age (old vs. young) and found that the losses were larger for older individuals (older than 40). However, with the richest specification of the propensity score used in the current version it did not balance for age groups. Thus, we have decided to report only the cohort effects here.
} 
employment rates are strongly negatively affected throughout the reported period (see the third panel in figure 4). The employment losses of the group with "new" capital, on the other hand, are smaller and restricted to the first three years after job loss. We take these results as evidence that part of the capital acquired under the Soviet regime is obsolete, which makes it difficult for displaced workers with human capital acquired under central planning to find re-employment. However, independent of the cohort to which displaced workers belong there are no relative earnings losses for those who find re-employment (fourth panel in figure 4).

The last characteristic that we investigate is educational attainment. Displaced workers with tertiary education incur substantially smaller earnings losses than displaced workers with at most secondary education, and this even though the average wages of the controls from the first group are much higher. For example at the time of job loss highly educated controls have average monthly earnings of about 17000 Rubles while controls with low education have average monthly earnings of only 10600 Rubles. Given that the absolute short-run earnings losses are larger for workers with low education and that earnings losses remain persistent only for this group, university trained workers seem to encounter little problems in finding new employment with a remuneration, which is similar to the one received in the old job. This can also be seen with the profiles of hourly wages for the two groups, where workers with low education have persistent wage losses, while highly educated workers encounter a significant wage penalty only during the quarter of the actual job loss. A difference in job search effectiveness can be clearly seen in the third panel of figure 5, which shows losses in terms of employment rates. Highly educated displaced workers converge to the employment rates of the controls about two years after job loss while displaced workers with low education have a significant deficit 
in the employment rate that never falls below 14 percentage points throughout the period. As in the case of the other characteristics there are no hourly wage penalties for those among the two sub-groups who find re-employment.

Summarizing the results of this analysis of labor market outcomes for the chosen sub-groups, we find that in all cases the costs of job loss are foregone earnings due to non-employment spells. Relative wage penalties for the re-employed cannot be established for any of the sub-groups, neither in the short- nor in the long-term. We also show that the costs of job loss do not differ by gender. On the other hand, our evidence points to the existence of types of workers who are particularly hard hit by job loss, namely workers with low education and “old” capital. For workers who are displaced from state and private firms the results are less clear cut. Workers dismissed from state firms encounter larger relative losses in the short-run than their counterparts who are laid off from private firms. The situation is reversed in the longer term since workers coming from private firms have more persistent losses in monthly earnings and hourly wages.

Labor market outcomes that are not standard in the literature are presented in table 3 for the entire sample of re-employed displaced workers. The first four columns deal with job security upon re-employment. There is a substantial penalty for displaced workers in terms of permanent contracts. Focusing on the propensity score results, we can see that displaced workers have a reduced likelihood of concluding a permanent written contract, which is persistent over the entire period. The mirror image of this is an increased probability to have an informal employment relationship, which we proxy with the oral agreement without a written contract. This increased probability is between 4 and 10 percent and increasing in the quarters of job loss, i.e. the more time has passed since job loss occurred the larger the probability that a re-employed displaced person finds 
himself or herself in an informal job. Hence, even in times of strong economic growth displacement is associated with increased employment insecurity and an increased number of low quality jobs.

The second type of non-standard outcome we are interested in is the number and value of fringe and in-kind benefits (columns 5-8 of table 3). The re-employed displaced workers encounter a relative loss of the number of benefits, amounting to between roughly one half and one benefit. However, there is no loss in terms of the value of benefits. These contrasting results seem to point to the fact if displaced workers find reemployment the benefits that they have lost upon job loss had some among them with low value while in their new jobs they receive less benefits than the non-displaced but this smaller number consists of benefits with larger value.

\section{Robustness Checks}

In most studies on job loss monthly earnings losses are calculated imputing zero earnings for displaced workers who are unemployed. As a robustness check we estimate earnings losses imputing monthly earnings of the unemployed by the level of unemployment benefits. In Russia only registered unemployed receive benefits. Since the supplement provides information on the level of these benefits for the registered unemployed at the beginning of their unemployment spell and for the last month they receive benefits, we re-estimate monthly earnings losses with the initial and the final level of benefits, using the propensity score matching procedure. Comparing the columns 2 and 3 of table $4 \mathrm{a}$ with the results in table 2 we find negligible differences between the two computing methods. The earnings losses are in general slightly smaller with unemployment benefits imputed as we would expect, but the levels as well as the persistence are very similar. 
A second robustness check consists in the tightening of the displacement definition. We exclude those workers from the displacement sample who separated from their jobs because of reasons 6 and 7 given in table A2. A "dismissal initiated by employer" as well as "personnel reduction” might entail individual layoffs connected to unsatisfactory performance or disciplinary problems. In addition, these two types of dismissals might hit low productivity workers especially hard who in all likelihood perform worse upon job loss than displaced workers who separated from their jobs for one of the reasons 1 through 5 given in table A2. There are some differences regarding monthly earnings losses (see column 3 in table 2 versus column 4 in table 4a). Between quarters 2 and 10 monthly earnings losses are smaller when we use the tighter definition of displacement hinting at the possibility that workers dismissed for reasons 6 and 7 are more likely to be of lower productivity and thus perform worse after job loss. This conjecture seems to be confirmed by the results regarding the other labor market outcomes. Losses in hours and the hourly wage as well as the shortfalls in the employment rates are smaller in table 4a than in table 2 throughout all quarters after displacement, confirming the "better quality" of the displaced when using the tighter definition. However, monthly earnings losses seem more persistent when we use the narrower definition of displacement. Finally, we do not find any wage penalty for reemployed narrowly defined displaced workers, a result common to all analyzed samples and sub-samples.

An especially vulnerable group among the displaced might be workers who are laid off without prior notification. This restricted set of displaced workers might in addition point to a selection problem, which manifests itself in particularly poor performance upon job loss. Employing this sample of the displaced we do find slightly 
higher monthly earnings losses (column 2 of table 4b). What is particularly striking is the persistence of these losses, which are absent with the broader definition of displacement. However, when we compare losses in hours worked and shortfalls in the employment rates there are no discernible differences for the two samples. Again, also for this sample there is no evidence of a relative wage penalty for the re-employed.

Our next robustness check alters the definition of controls by keeping only stayers in this group. In the early literature on displacement stayers were used to construct a counterfactual. However, more recently students of displacement have argued that stayers are too "stable" a group to be a credible counterfactual for the displaced. Instead, both stayers and quitters should be used for the construction of this credible counterfactual, since for a displaced worker the non-treatment state might be either staying at the firm or quitting the firm. In times of strong economic growth most workers who quit their firm should relatively rapidly find new employment with earnings conditions that might be at least as good as in the old job. Only if there is a substantial fraction of quitters who have difficulties finding a new job, should removing them from the sample of controls lead to upward biases regarding losses in labor market outcomes. Comparing columns 6 through 8 in table $4 \mathrm{~b}$ with the respective columns in table 2, we find slightly higher losses at some quarters, but in general upward biases are not visible. Again, also with this control group no relative wage penalty can be detected.

The last robustness check redefines the labor market outcome "informality" by stipulating that a job is informal if workers do not receive paid holidays, sick pay and maternity/paternity benefits on the job. This definition is more encompassing than using an oral contract as the defining criterion: virtually all displaced workers on oral contracts lack the receipt of the three fringe benefits, while a substantial fraction the displaced who 
are on permanent contracts also does not receive these benefits. Table 5 presents the fixed effects and the matching results using this alternative definition of informality as the labor market outcome of interest. Both sets of results are substantially higher than the results with an oral contract as the basis of the definition of informality (columns 4 and 5 of table 3). Particularly striking is the fact that there is an increased likelihood of being informal even before displacement takes place. Hence, when the absence of the three main fringe benefits defines an informal job, displaced workers in Russia experience slightly more job insecurity than the rest of the workforce even before job loss occurs.

Our robustness checks have shown that the large losses in monthly earnings, the hourly wage, hours worked and the employment rate are present whatever sample of displaced or controls or definitions of labor market outcomes we use. They also establish that in the case of especially vulnerable groups the losses are somewhat larger. One result that is also never altered is the absence of a wage penalty for re-employed displaced workers.

\section{Conclusions}

We use a unique data base that combines the main RLMS panel data set of the years 2003 to 2008 with a supplement on displacement that was administered with the main $17^{\text {th }}$ wave of the RLMS in the months of October to December 2008. The supplement is comprised for the most part of retrospective data covering the years 2003 to 2008. A first analysis of the retrospective data on monthly earnings produces evidence that potential measurement error due to recall bias is not correlated with the treatment (displacement). It is, therefore, very unlikely that our results are driven by recall bias. 
To address selection problems connected to displacement we employ fixed effects regressions and propensity score matching techniques. With the latter approach we invoke the conditional independence assumption which says that once we match controls and the displaced on the propensity score there are no differences in unobserved characteristics that impact on the labor market outcomes that we analyze: monthly earnings, hours worked, hourly wages, employment, hourly wages upon re-employment, number and value of benefits and the likelihood of having an informal job. We are quite confident that we can establish a causal effect of displacement on these outcomes.

We find large and persistent income losses as a consequence of displacement due to a fall in hours worked and employment. We never establish a wage penalty for those displaced who find new employment. So, like in many European countries the costs of job loss in Russia are foregone earnings due to long spells of non-employment. Robustness checks that use different definitions of displacement or alter the composition of the control group confirm this result unequivocally.

We splice the data by gender and, in addition, look at specific sub-groups in order to understand, which types of individuals are particularly vulnerable to the consequences of job loss and whether the loss of firm-specific human capital or obsolete human capital from Soviet times can explain these costs of job loss. Gender is not a dividing characteristic as far as the costs of job loss are concerned. Workers displaced from state firms have higher earnings in the short run than workers who experience a layoff from a private firm. This relationship is reversed in the longer term as the loss in firm-specific human capital seems to hit workers from private firms harder than those laid off from state firms. We also show that obsolete skills acquired under the Soviet regime makes it more difficult for older workers to find re-employment than for those displaced workers 
who accumulated labor market experience and human capital during the transition. We also show that workers with at most primary education have a much harder time to flow back into employment upon job loss than workers with tertiary education, which is reflected in much larger and more persistent earnings losses of the former group.

The analysis on non-conventional labor market outcomes shows increased job insecurity for Russian displaced workers since upon re-employment they persistently have a reduced likelihood of concluding a permanent written contract. The mirror image of this is an increased probability to have an informal employment relationship, which we proxy with the oral agreement without a written contract. This increased probability is between 4 and 10 percent and increasing in the quarters of job loss, i.e. the more time has passed since job loss occurred the larger the probability that a re-employed displaced person finds himself or herself in an informal job. We also find that re-employed displaced workers encounter a relative loss of the number of benefits, amounting to between roughly one half and one benefit. However, there is no loss in terms of the value of benefits. This latter result seems to say that benefits in new jobs, while less numerous, have higher unit value.

The central point of interest for policy makers that our evidence establishes is that no matter which sample we use and how we split the sample, the costs of job loss in Russia consist in large foregone earnings due to less employment and less hours worked and not in wage penalties upon re-employment. This is maybe not that surprising given that we report about displacement in a period of growth when earnings in the dominant private sector grow steadily. The main policy conclusion from this result points at the great importance of job brokerage by the state and courses that entice displaced workers to improve the efficacy of their job search. 


\section{References}

Borisov, Vadim (2001) Social Partnership in Russia: Country Specifics or Misuse of the Concept? Sotsiologicheskie issledovaniia (Sociological Research), No. 5: 56-66.

Borisov, Vadim and Simon Clarke (2006) The Rise and Fall of Social Partnership in Postsocialist Europe: the Commonwealth of Independent States. Industrial Relations Journal, 37(6): 607-629.

Cazes, Sandrine (2002) Do Labor Market Institutions Matter in Transition Economies? An Analysis of Labour Market Flexibility in the Late Nineties. ILO, International Institute for Labour Studies, Discussion Paper 140/2002.

Couch, Kenneth A. and Dana W. Placzek (2010) Earnings losses of displaced workers revisited, American Economic Review 100 (1): 572-589.

Denisova, Irina and Marcus Svedberg (2007) The Governance of Economic and Employment Development in North West Russia. In: Silvain Giguere (ed.) Baltic Partnerships: Integration, Growth, and Local Governance in the Baltic Sea Region. OECD Publishing, Paris.

Djankov, Simeon, Murrell, Peter (2002) Enterprise restructuring in transition: a quantitative Survey, Journal of Economic Literature, 60: 739-792.

Dolgopiatova, Tatiana (2007) Ownership Concentration and Russian Company Development, Problems of Economic Transition 50 (5): 7-23.

Eichhorst, Werner, Michael Feil and Christoph Braun (2008) What Have We Learned? Assessing Labor Market Institutions and Indicators, IZA Discussion Papers 3470, Institute for the Study of Labor (IZA).

Filatotchev, Igor, Mike Wright, and Michael Bleaney (1999) Privatization, Insider Control and Managerial Entrenchment in Russia, Economics of Transition 7: 481-504.

Gimpelson, Vladimir, Kapeliushnikov, Rostislav, and Anna Lukiyanova (2010) Employment Protection Legislation in Russia: Regional Enforcement and Labour Market Outcomes. Comparative Economic Studies 52 (4): 611 - 636.

Hare, Paul, and Muravyev, Alexander (2003) Privatization in Russia, in: D. Parker, D. Saal (eds.) International Handbook on Privatization, Edward Elgar Publishing, Cheltenham, UK.

Heckman, James J., LaLonde, Robert J., Smith, Jeffrey A. (1999) The economics and econometrics of active labor market programs. In: Ashenfelter, Orley, Card, David (Eds.). Handbook of Labor Economics 3. Elsevier, Amsterdam.

Heckman, James J. and Smith, Jerry A. (1995) Assessing the case for social experiments, Journal of Economic Perspectives 9 (2): 85-110.

Hijzen, Alexander, Upward Richard and Peter W. Wright (2010) The income losses of displaced workers, Journal of Human Resources, 45 (1): 243-269.

Ichino, Andrea, Schwerdt Guido, Winter-Ebmer Rudolf and Josef Zweimüller (2007) Too Old to Work, Too Young to Retire? IZA Discussion Paper No. 3110, October. 
Kletzer, Lorie G. and Robert W. Fairlie (2003) The Long-Term Costs of Job Loss for Young Adult Workers, Industrial Labor Relations Review, 56 (4): 682-698.

Kuhn, Peter - Ed. (2002) Losing Work, Moving On: Worker Displacement, an InternationalPerspective. W. E. Upjohn Institute for Employment Research.

Lechner, M. (2001). Identification and estimation of causal effects of multiple treatments under the conditional independence assumption. In M. Lechner and F. Pfeiffer (Eds.), Econometric Evaluation of Labour Market Policies. Heidelberg: Physica.

Lehmann, Hartmut, Philips, Kaja and Jonathan Wadsworth (2005) The Incidence and Cost of Job Loss in a Transition Economy: Displaced Workers in Estonia, 1989-1999. Journal of Comparative Economics, 33: 59-87.

Lehmann, Hartmut, Pignatti, Norberto and Jonathan Wadsworth (2006) The Incidence and Cost of Job Loss in the Ukrainian Labor Market. Journal of Comparative Economics, 34: 248-271.

Lehmann, Hartmut and Alexander Muravyev (2010) Labor Market Institutions and Labor Market Performance: What Can We Learn from Transition Countries? Working Paper No. 714, Department of Economics, University of Bologna.

Muravyev, Alexander (2010) Evolution of Employment Protection Legislation in the USSR, CIS and Baltic States, 1985-2009. IZA Discussion Paper No. 5365, Institute for the Study of Labor (IZA).

Neal, Derek (1995) Industry-specific human capital: Evidence from displaced workers, Journal of Labor Economics 13, 653-677.

OECD (2009) Employment Outlook, OECD, Paris.

Orazem, Peter, Vodopivec, Milan and Ruth Wu (2004) Worker displacement during the transition: Experience from Slovenia, Economics of Transition 13: 311-340.

Rosenbaum, P.R. and D.B. Rubin (1983) The central role of the Propensity Score in observational studies for causal effects, Biometrika 70: 41-55.

Schwerdt, Guido, Ichino Andrea, Ruf Oliver, Winter-Ebmer Rudolf and Josef Zweimüller (2010) Does the Color of the Collar Matter? Firm Specific Human Capital and Post-Displacement Outcomes, Economic Letters 108 (2): 137-140.

Smith, Peter J. (2002) Analysis of Survival and Failure Data, Chapman Hall, London.

Sullivan, Daniel and Till von Wachter (2009) Job displacement and mortality: An analysis using administrative data, Quarterly Journal of Economics 124 (3): 1265-1306.

United States Bureau of Labor Statistics - U.S.BLS (2010) Extended Mass Layoffs in 2009, Report 1025, Department of Labor, Washington D.C., December.

Venn, Daniele (2009) Legislation, Collective Bargaining and Enforcement: Updating the OECD Employment Protection Indicators. OECD Social, Employment and Migration Working Paper No. 89.

World Bank (2003) The Russian Labor Market: Moving from Crisis to Recovery, International Bank for Reconstruction and Development/World Bank, Washington. 
World Bank (2007) Informality: Exit and Exclusion. International Bank for Reconstruction and Development/World Bank, Washington. 


\section{FIGURES}

Figure 1: Separations and Layoffs

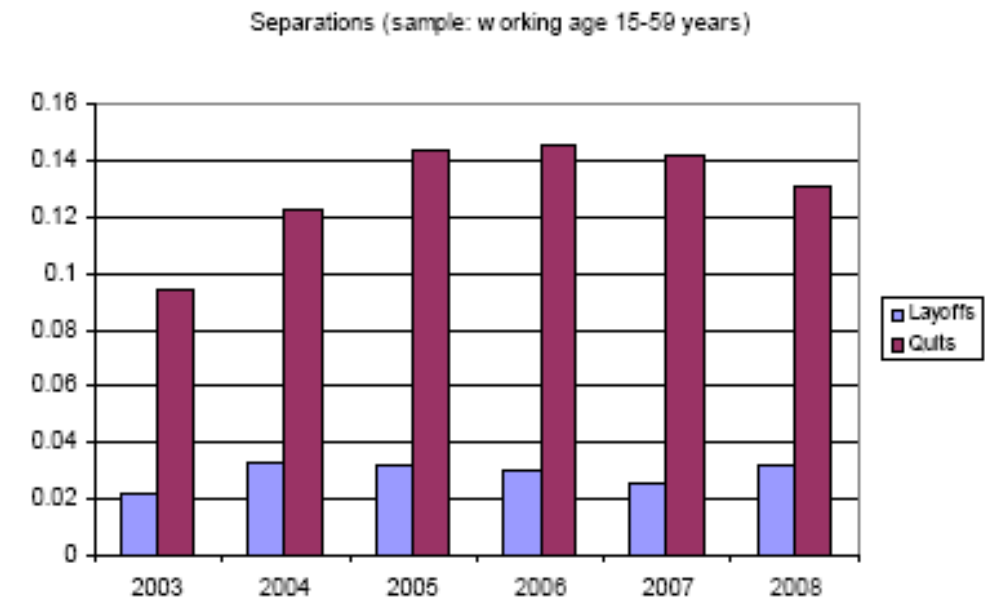

Layoffs (sample: w orking age 15-59 years)

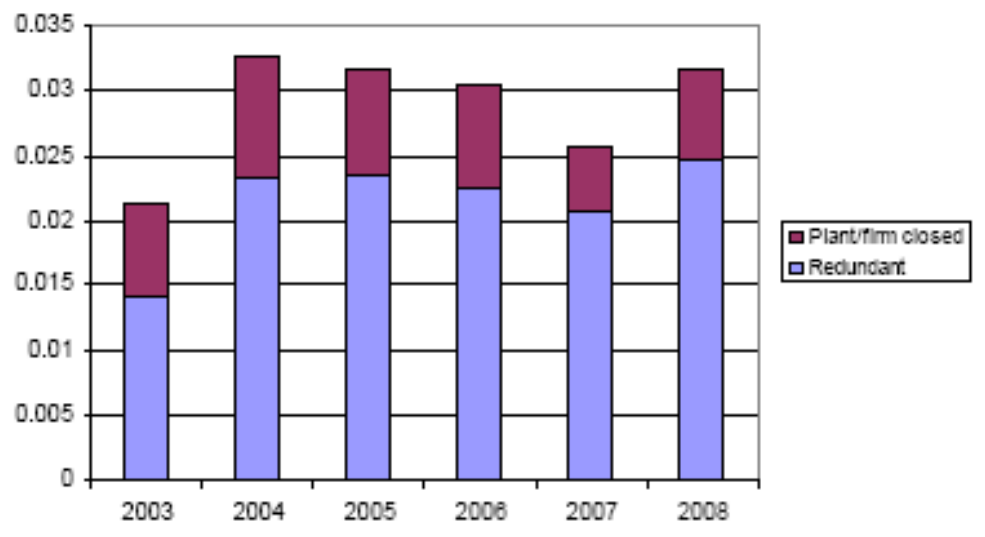

Source: Authors' calculations based on RLMS supplement on displacement. 


\section{Labor market outcomes by sub-groups}

Figure 2: Males vs. females
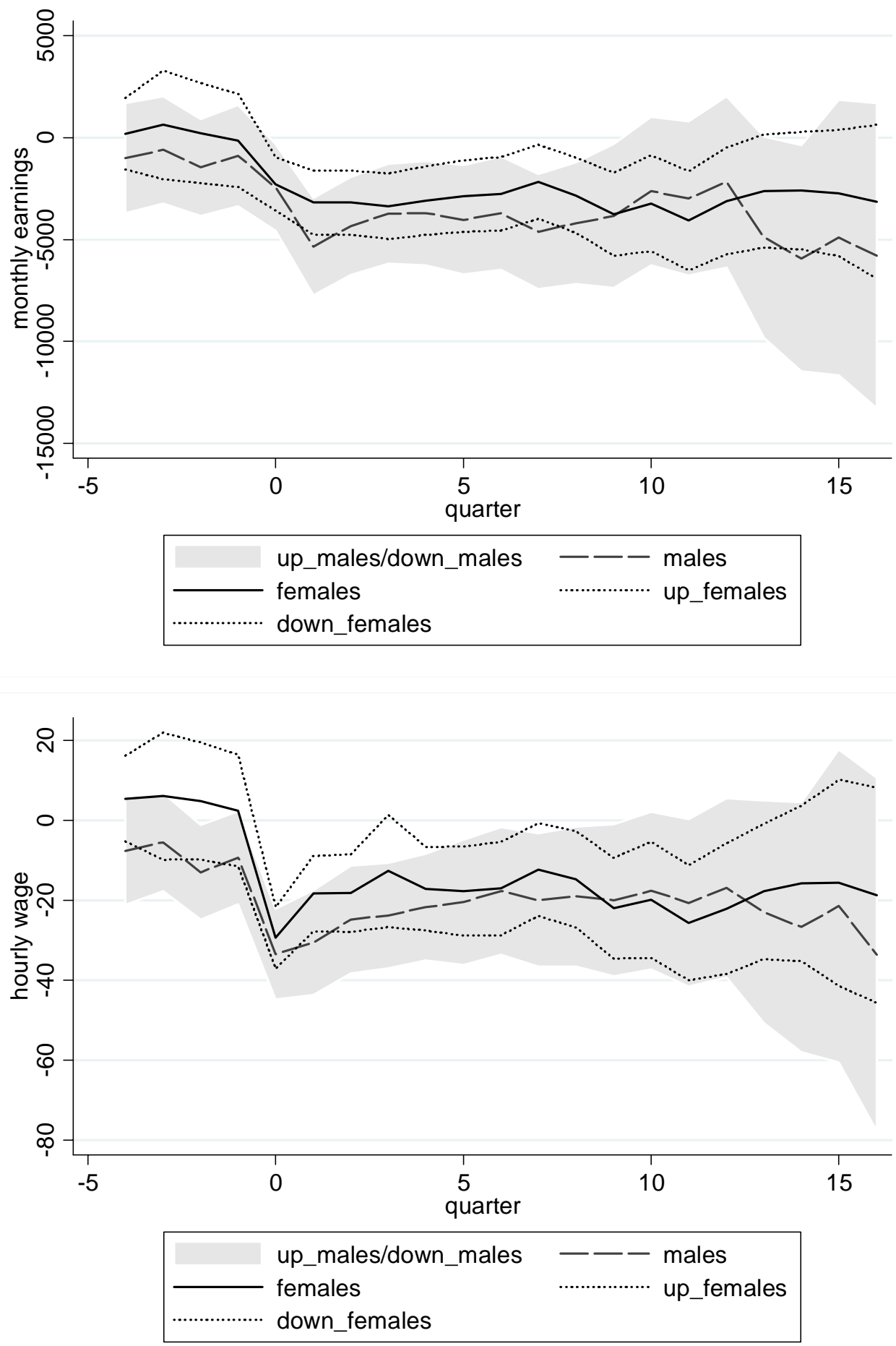

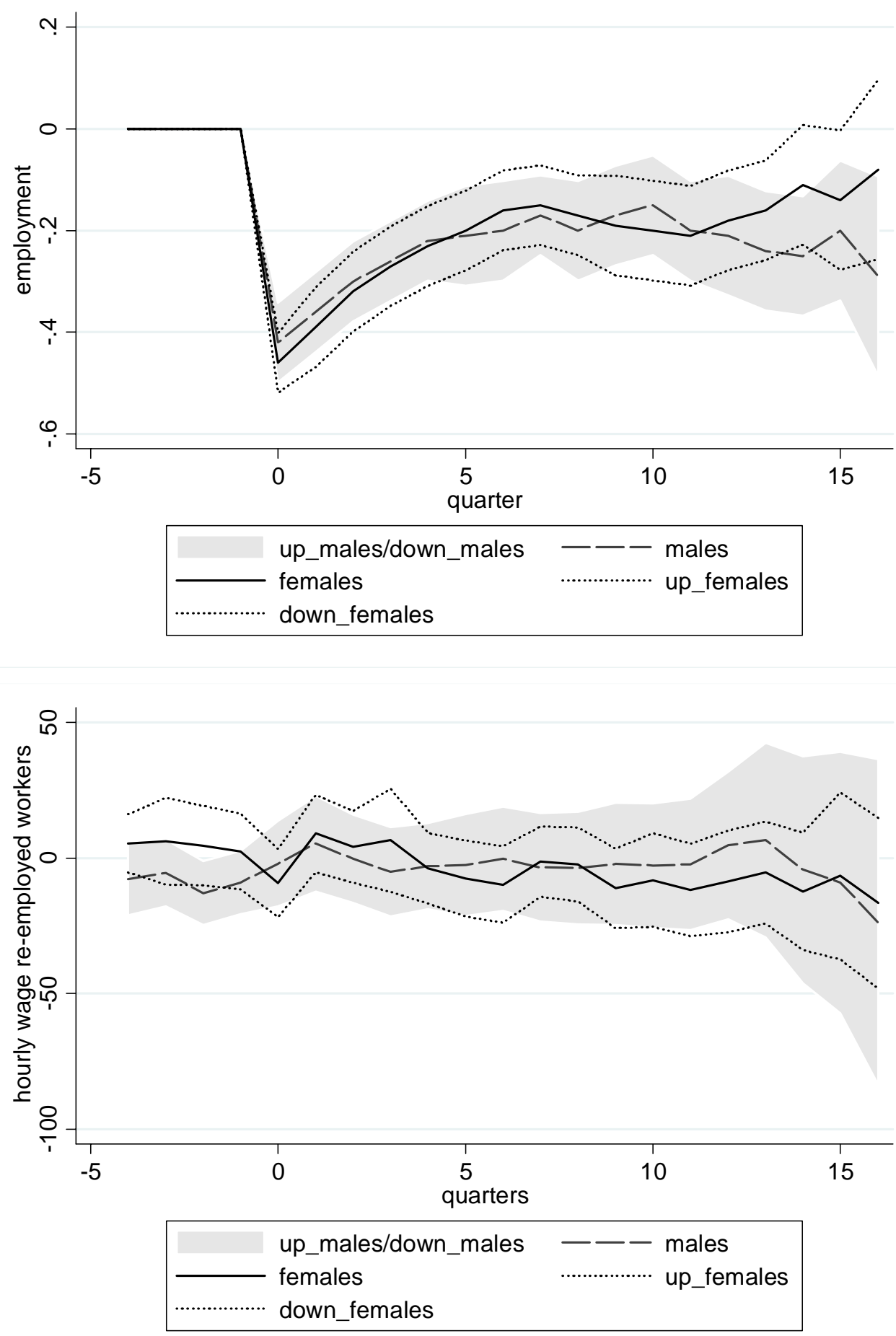
Figure 3: previous employment in state vs. private firm
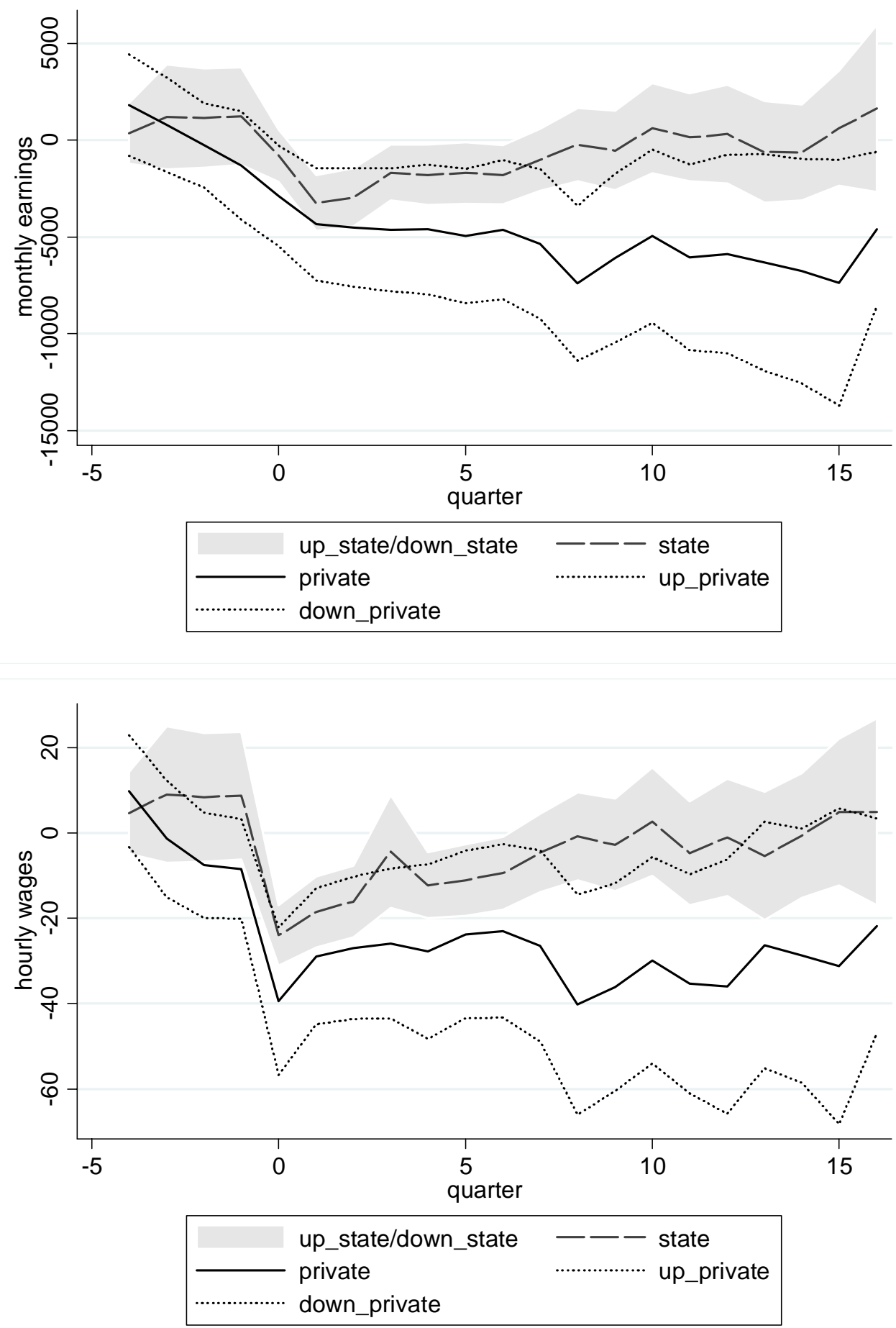

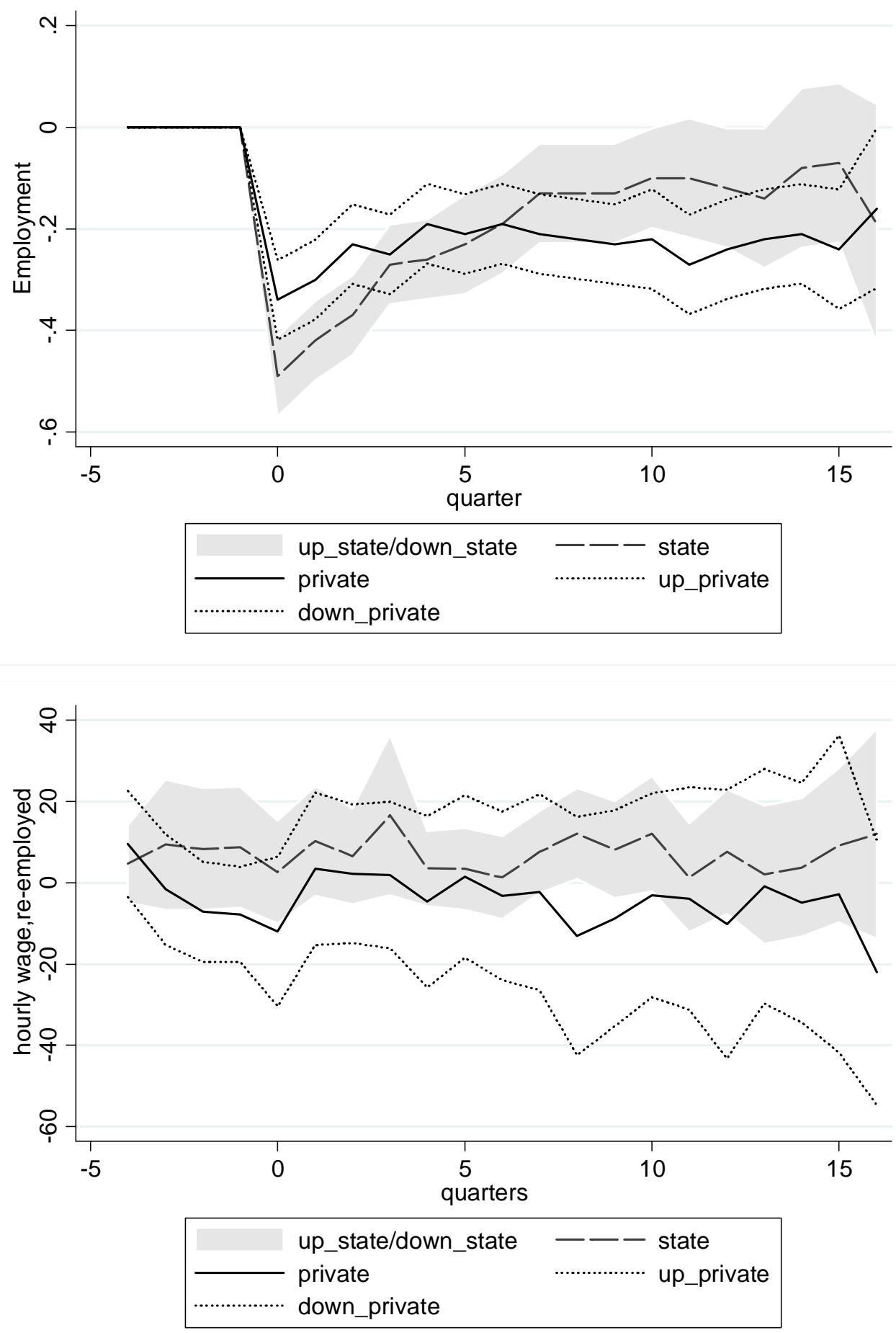
Figure 4: Workers older than 18 years in 1991 vs. workers younger than or equal to 18 years in 1991
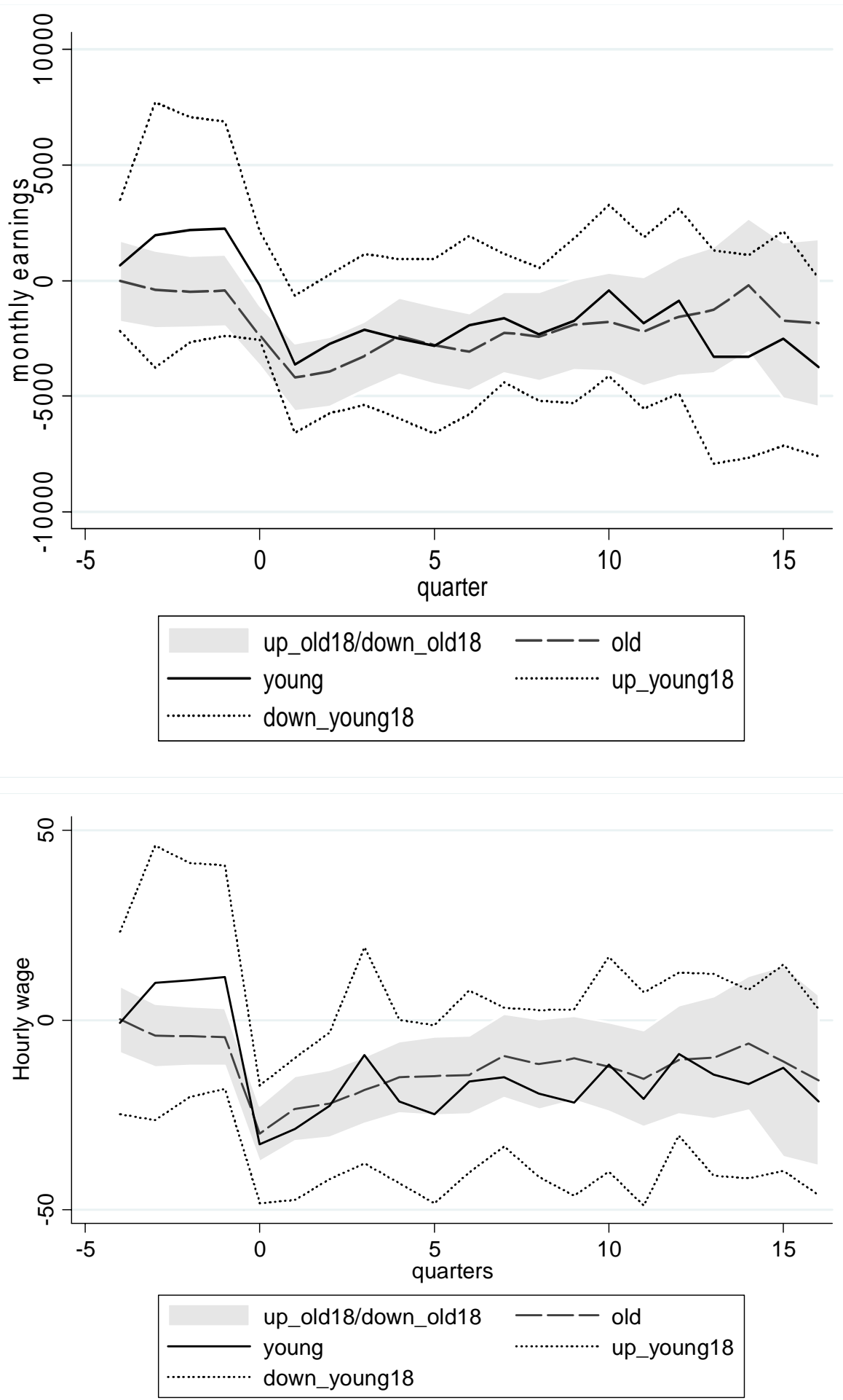


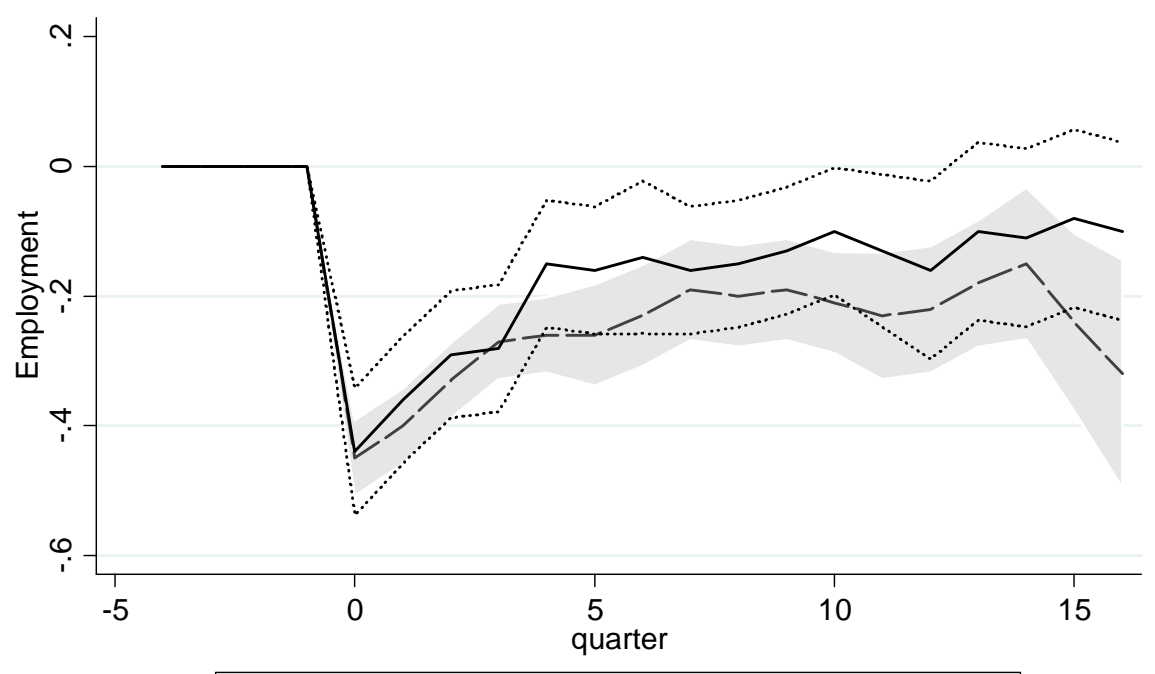

up_old18/down_old18 - - old

young

up_young18

down_young18

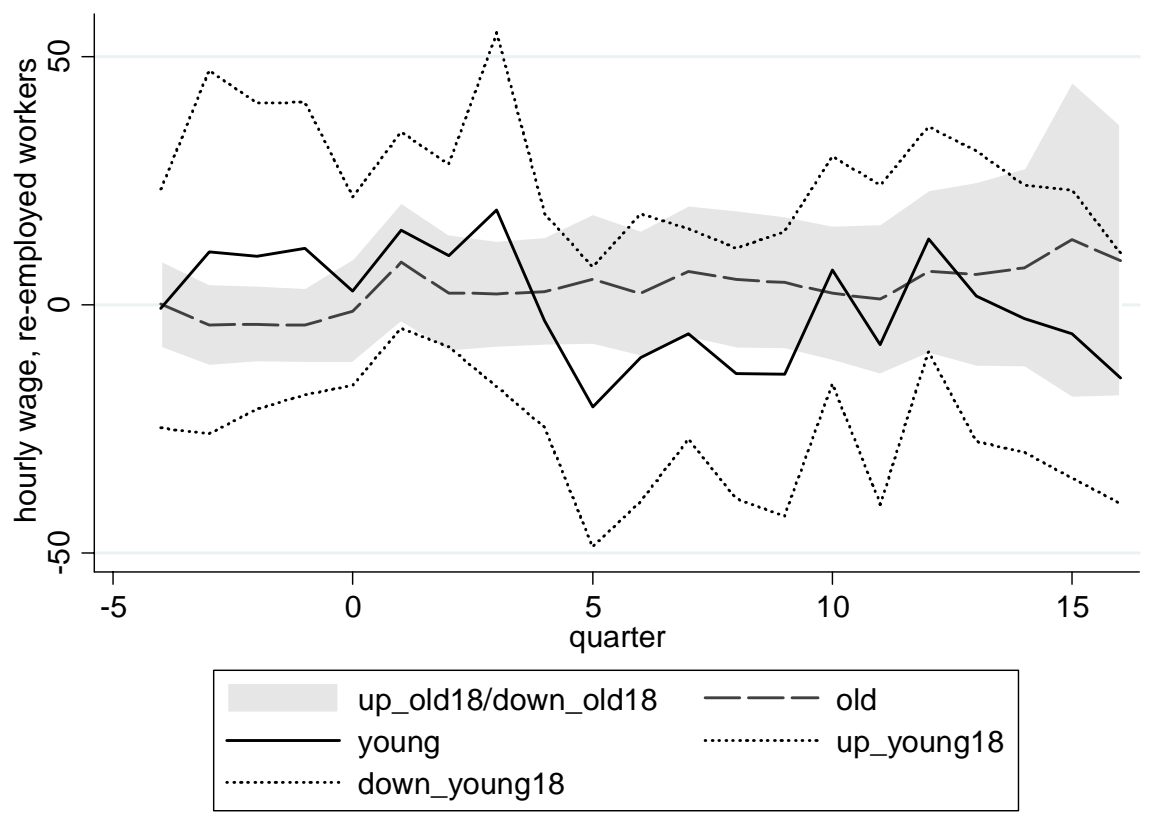


Figure 5: Higher (tertiary) vs. secondary or lower education
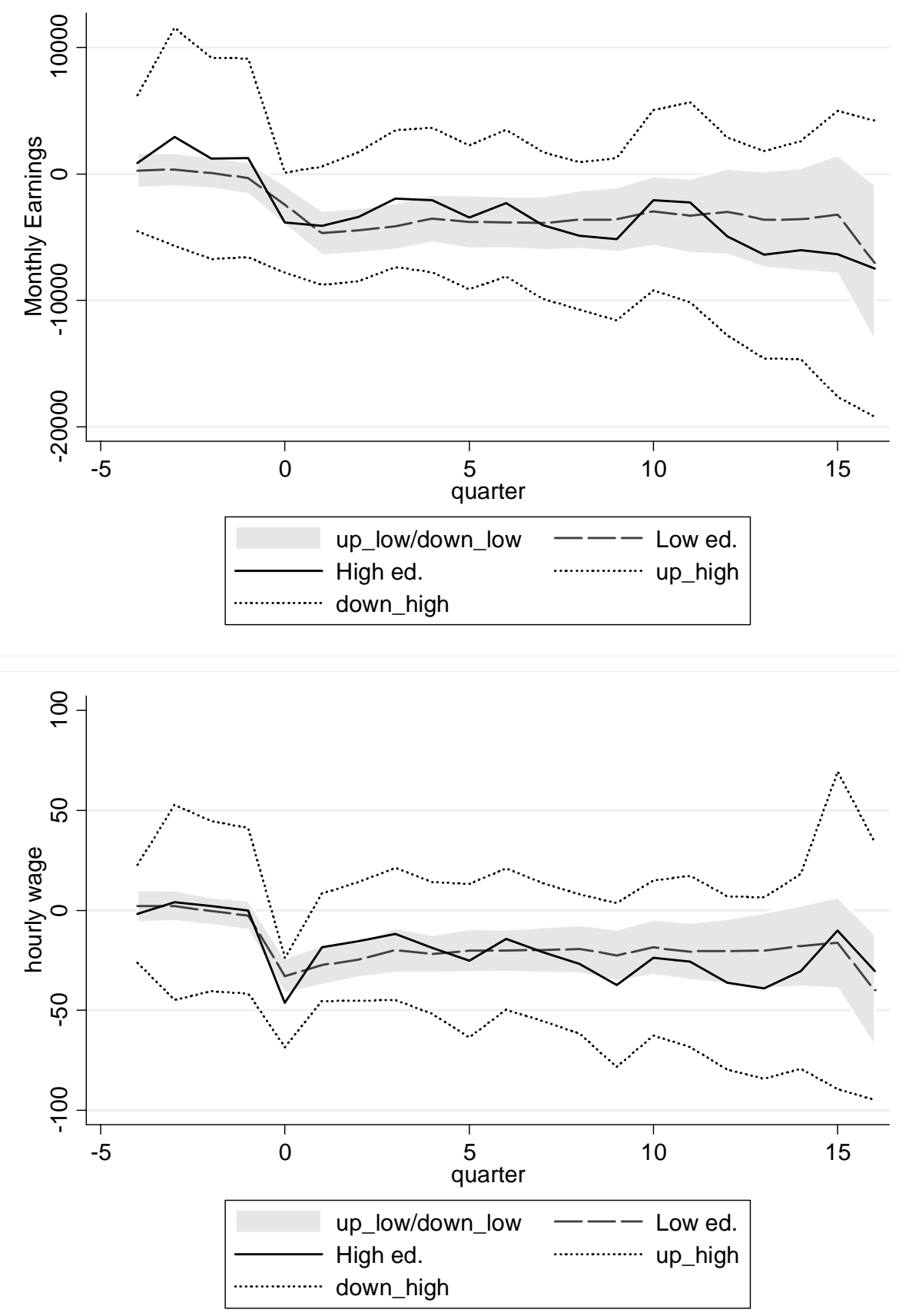

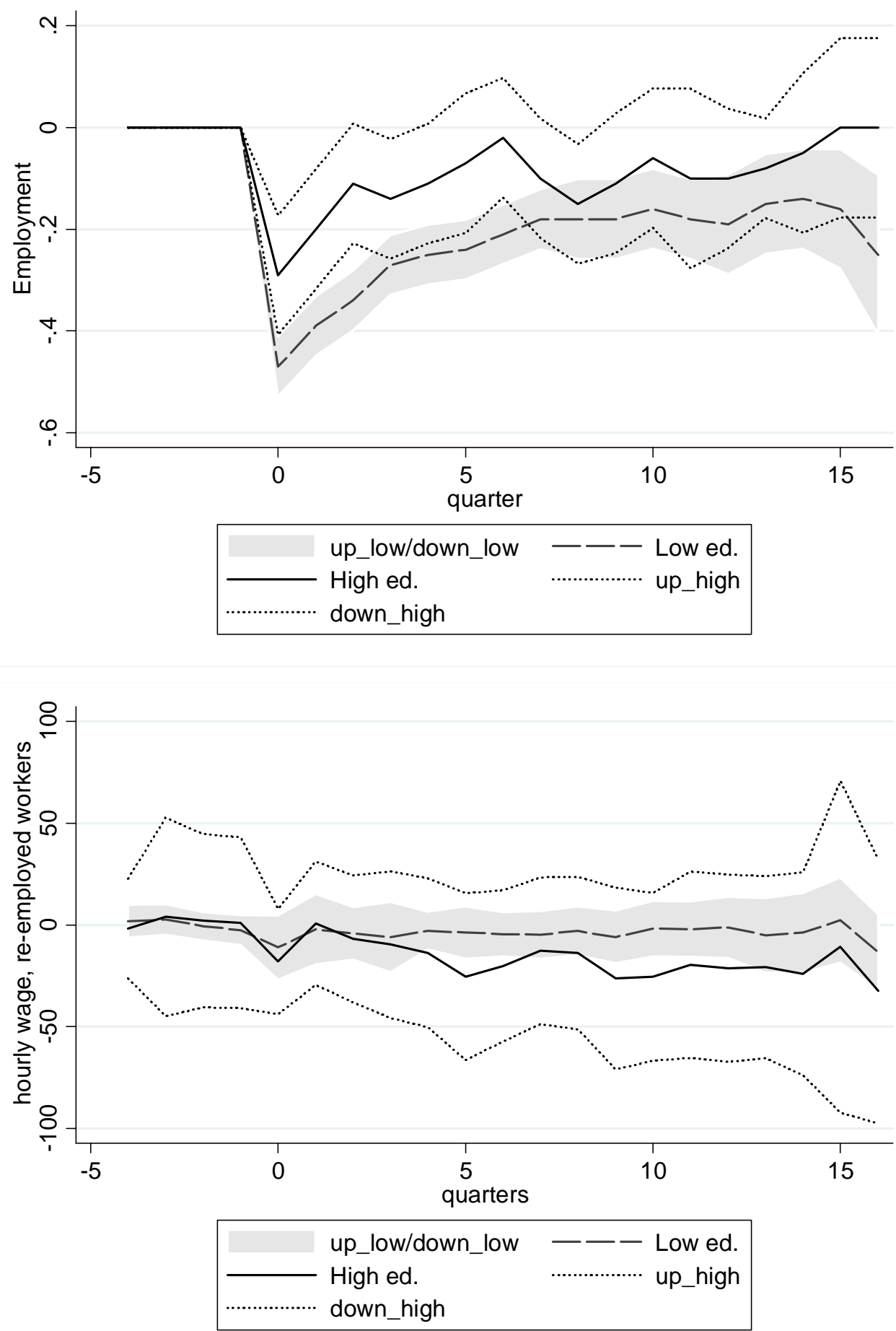

Source: Authors' calculations based on RLMS panel data and RLMS supplement on displacement. 
TABLES

Table 1: Observable characteristics used for propensity score matching and their balance

\begin{tabular}{|c|c|c|c|c|c|}
\hline & & $\begin{array}{c}\text { Mean } \\
\text { Treated }\end{array}$ & $\begin{array}{c}\text { Mean } \\
\text { Controls }\end{array}$ & $\begin{array}{c}\text { Standardized } \\
\text { bias }\end{array}$ & $\mathrm{p}>|\mathrm{t}|$ \\
\hline \multirow[t]{2}{*}{ Age } & $\mathrm{U}$ & 39.811 & 39.560 & 2.378 & 0.042 \\
\hline & M & 39.811 & 40.058 & -2.338 & 0.738 \\
\hline \multirow[t]{2}{*}{ Male } & $\mathrm{U}$ & 0.429 & 0.449 & -4.067 & 0.776 \\
\hline & M & 0.429 & 0.462 & -6.573 & 0.337 \\
\hline \multirow[t]{2}{*}{ Married } & $\mathrm{U}$ & 0.744 & 0.772 & -6.690 & 0.086 \\
\hline & M & 0.744 & 0.755 & -2.721 & 0.694 \\
\hline \multirow[t]{2}{*}{ Tenure } & $\mathrm{U}$ & 110.862 & 120.225 & -7.875 & 0.075 \\
\hline & M & 110.862 & 103.790 & 5.948 & 0.370 \\
\hline \multirow[t]{2}{*}{ State owned firm } & $\mathrm{U}$ & 0.524 & 0.609 & -17.210 & 0.000 \\
\hline & M & 0.524 & 0.512 & 2.590 & 0.708 \\
\hline \multirow[t]{2}{*}{ Hours worked per week } & $\mathrm{U}$ & 42.738 & 41.957 & 7.625 & 0.209 \\
\hline & M & 42.738 & 42.969 & -2.257 & 0.759 \\
\hline \multirow[t]{2}{*}{ Monthly earnings } & $\mathrm{U}$ & 9979.832 & 10809.80 & -9.200 & 0.712 \\
\hline & M & 9979.832 & 9949.681 & 0.334 & 0.959 \\
\hline \multirow[t]{2}{*}{ Primary education } & $\mathrm{U}$ & 0.093 & 0.083 & 3.543 & 0.684 \\
\hline & M & 0.093 & 0.100 & -2.464 & 0.729 \\
\hline \multirow[t]{2}{*}{ Secondary education } & $\mathrm{U}$ & 0.732 & 0.657 & 16.359 & 0.000 \\
\hline & M & 0.732 & 0.737 & -1.015 & 0.877 \\
\hline \multirow[t]{2}{*}{ Higher education } & $\mathrm{U}$ & 0.175 & 0.260 & -20.756 & 0.000 \\
\hline & M & 0.175 & 0.163 & 2.839 & 0.649 \\
\hline \multirow[t]{2}{*}{ North-West } & $\mathrm{U}$ & 0.077 & 0.082 & -1.779 & 0.320 \\
\hline & M & 0.077 & 0.093 & -6.034 & 0.392 \\
\hline \multirow[t]{2}{*}{ Central-Volga } & $\mathrm{U}$ & 0.298 & 0.364 & -13.884 & 0.001 \\
\hline & M & 0.298 & 0.275 & 4.962 & 0.451 \\
\hline \multirow[t]{2}{*}{ South } & $\mathrm{U}$ & 0.107 & 0.143 & -10.935 & 0.102 \\
\hline & M & 0.107 & 0.117 & -2.819 & 0.665 \\
\hline \multirow[t]{2}{*}{ Moscow-St.Petersburg } & $\mathrm{U}$ & 0.200 & 0.184 & 4.296 & 0.257 \\
\hline & M & 0.200 & 0.152 & 12.423 & 0.060 \\
\hline \multirow[t]{2}{*}{ Written permanent contract } & $\mathrm{U}$ & 0.930 & 0.936 & -2.494 & 0.993 \\
\hline & M & 0.930 & 0.930 & 0.000 & 1.000 \\
\hline \multirow[t]{2}{*}{ Written temporary contract } & $\mathrm{U}$ & 0.033 & 0.038 & -3.111 & 0.128 \\
\hline & M & 0.033 & 0.037 & -2.518 & 0.711 \\
\hline \multirow[t]{2}{*}{ “dogovor podriada” } & $\mathrm{U}$ & 0.007 & 0.006 & 1.096 & 0.980 \\
\hline & M & 0.007 & 0.009 & -2.888 & 0.705 \\
\hline \multirow[t]{2}{*}{ Oral agreement } & $\mathrm{U}$ & 0.030 & 0.019 & 7.147 & 0.033 \\
\hline & M & 0.030 & 0.023 & 4.501 & 0.527 \\
\hline \multirow[t]{2}{*}{ Firm size: $1-5$} & $\mathrm{U}$ & 0.049 & 0.040 & 4.122 & 0.392 \\
\hline & M & 0.049 & 0.040 & 4.510 & 0.507 \\
\hline \multirow[t]{2}{*}{ Firm size: 6-20 } & $\mathrm{U}$ & 0.156 & 0.133 & 6.611 & 0.028 \\
\hline & M & 0.156 & 0.138 & 5.302 & 0.441 \\
\hline
\end{tabular}




\begin{tabular}{|c|c|c|c|c|c|}
\hline \multirow[t]{2}{*}{ Firm size: $21-50$} & $\mathrm{U}$ & 0.198 & 0.160 & 9.879 & 0.191 \\
\hline & M & 0.198 & 0.217 & -4.865 & 0.501 \\
\hline \multirow[t]{2}{*}{ Firm size: 51-100 } & $\mathrm{U}$ & 0.156 & 0.168 & -3.239 & 0.933 \\
\hline & M & 0.156 & 0.166 & -2.528 & 0.711 \\
\hline \multirow[t]{2}{*}{ Firm size: $101-500$} & $\mathrm{U}$ & 0.193 & 0.240 & -11.227 & 0.011 \\
\hline & M & 0.193 & 0.196 & -0.566 & 0.931 \\
\hline \multirow[t]{2}{*}{ Firm size: $>500$} & $\mathrm{U}$ & 0.247 & 0.259 & -2.643 & 0.287 \\
\hline & M & 0.247 & 0.245 & 0.536 & 0.937 \\
\hline \multirow[t]{2}{*}{ Light and Food Industry } & $\mathrm{U}$ & 0.082 & 0.064 & 6.890 & 0.058 \\
\hline & M & 0.082 & 0.072 & 3.592 & 0.609 \\
\hline \multirow[t]{2}{*}{ Civil Machine Building } & $\mathrm{U}$ & 0.056 & 0.056 & 0.042 & 0.773 \\
\hline & M & 0.056 & 0.061 & -2.028 & 0.771 \\
\hline \multirow[t]{2}{*}{ Military Industrial Complex } & $\mathrm{U}$ & 0.019 & 0.026 & -5.086 & 0.299 \\
\hline & M & 0.019 & 0.019 & 0.000 & 1.000 \\
\hline \multirow[t]{2}{*}{ Oil and Gas } & $\mathrm{U}$ & 0.019 & 0.026 & -5.266 & 0.159 \\
\hline & M & 0.019 & 0.030 & -7.847 & 0.270 \\
\hline \multirow[t]{2}{*}{ Other Heavy Industry } & $\mathrm{U}$ & 0.030 & 0.034 & -2.112 & 0.750 \\
\hline & $\mathrm{M}$ & 0.030 & 0.023 & 3.961 & 0.527 \\
\hline \multirow[t]{2}{*}{ Construction } & $\mathrm{U}$ & 0.110 & 0.066 & 15.531 & 0.001 \\
\hline & M & 0.110 & 0.098 & 4.131 & 0.576 \\
\hline \multirow[t]{2}{*}{ Transportation, Communication } & $\mathrm{U}$ & 0.068 & 0.097 & -10.562 & 0.091 \\
\hline & M & 0.068 & 0.072 & -1.700 & 0.789 \\
\hline \multirow[t]{2}{*}{ Agriculture } & $\mathrm{U}$ & 0.110 & 0.069 & 14.387 & 0.000 \\
\hline & M & 0.110 & 0.131 & -7.377 & 0.345 \\
\hline \multirow[t]{2}{*}{ Governement and Public Adm. } & $\mathrm{U}$ & 0.016 & 0.021 & -3.419 & 0.301 \\
\hline & M & 0.016 & 0.012 & 3.446 & 0.561 \\
\hline \multirow[t]{2}{*}{ Education } & $\mathrm{U}$ & 0.070 & 0.124 & -18.225 & 0.000 \\
\hline & M & 0.070 & 0.063 & 2.374 & 0.681 \\
\hline \multirow[t]{2}{*}{ Science and Culture } & $\mathrm{U}$ & 0.007 & 0.030 & -16.959 & 0.001 \\
\hline & M & 0.007 & 0.009 & -1.743 & 0.705 \\
\hline \multirow[t]{2}{*}{ Health } & $\mathrm{U}$ & 0.042 & 0.086 & -18.095 & 0.000 \\
\hline & M & 0.042 & 0.042 & 0.000 & 1.000 \\
\hline \multirow{2}{*}{$\begin{array}{l}\text { Defense, Ministry Internal } \\
\text { Affairs, Security Service }\end{array}$} & $\mathrm{U}$ & 0.035 & 0.053 & -8.643 & 0.009 \\
\hline & M & 0.035 & 0.035 & 0.000 & 1.000 \\
\hline \multirow[t]{2}{*}{ Trade, Consumer Services } & $\mathrm{U}$ & 0.142 & 0.099 & 13.414 & 0.000 \\
\hline & $\mathrm{M}$ & 0.142 & 0.121 & 6.456 & 0.364 \\
\hline \multirow[t]{2}{*}{ Finances } & $\mathrm{U}$ & 0.023 & 0.017 & 4.365 & 0.695 \\
\hline & M & 0.023 & 0.030 & -4.964 & 0.527 \\
\hline \multirow[t]{2}{*}{ Energy (Power) Industry } & $\mathrm{U}$ & 0.021 & 0.020 & 0.849 & 0.248 \\
\hline & M & 0.021 & 0.030 & -6.595 & 0.388 \\
\hline \multirow[t]{2}{*}{ Housing and Communal Services } & $\mathrm{U}$ & 0.065 & 0.045 & 8.842 & 0.040 \\
\hline & M & 0.065 & 0.075 & -4.085 & 0.593 \\
\hline \multirow[t]{2}{*}{ Other } & $\mathrm{U}$ & 0.086 & 0.069 & 6.356 & 0.085 \\
\hline & $\mathrm{M}$ & 0.086 & 0.077 & 3.482 & 0.618 \\
\hline Military & $\mathrm{U}$ & 0.000 & 0.000 & 0.000 & 0.043 \\
\hline & M & 0.000 & 0.000 & & \\
\hline Legislators, senior managers, & $\mathrm{U}$ & 0.035 & 0.035 & -0.125 & 0.569 \\
\hline officials & M & 0.035 & 0.028 & 3.798 & 0.558 \\
\hline
\end{tabular}




\begin{tabular}{lccccc} 
Professionals & U & 0.128 & 0.192 & -17.372 & 0.000 \\
Technicians and Associate & $\mathrm{M}$ & 0.128 & 0.112 & 4.466 & 0.463 \\
$\quad$ Professionals & $\mathrm{U}$ & 0.163 & 0.174 & -2.952 & 0.714 \\
Clerks & $\mathrm{M}$ & 0.163 & 0.168 & -1.244 & 0.854 \\
& $\mathrm{U}$ & 0.061 & 0.060 & 0.289 & 0.859 \\
Service workers and market & $\mathrm{M}$ & 0.061 & 0.044 & 6.852 & 0.284 \\
$\quad \mathrm{U}$ & 0.103 & 0.086 & 5.632 & 0.252 \\
$\quad$ workers & $\mathrm{M}$ & 0.103 & 0.084 & 6.378 & 0.348 \\
Skilled agricultural and fishery & $\mathrm{U}$ & 0.009 & 0.005 & 5.603 & 0.314 \\
$\quad$ workers & $\mathrm{M}$ & 0.009 & 0.009 & 0.000 & 1.000 \\
Craft and related trades & $\mathrm{U}$ & 0.133 & 0.145 & -3.464 & 0.470 \\
& $\mathrm{M}$ & 0.133 & 0.172 & -11.454 & 0.107 \\
Plant and Machine operators & $\mathrm{U}$ & 0.231 & 0.190 & 10.099 & 0.111 \\
& $\mathrm{M}$ & 0.231 & 0.256 & -6.297 & 0.382 \\
Elementary unskilled workers & $\mathrm{U}$ & 0.138 & 0.114 & 7.181 & 0.005 \\
& $\mathrm{M}$ & 0.138 & 0.126 & 3.516 & 0.614 \\
\hline
\end{tabular}

U=Unmatched Sample; M=Matched Sample. Source: Authors' calculations based on RLMS supplement on displacement and main RLMS data. 
Table 2: The effect of displacement on labor market outcomes

\begin{tabular}{|c|c|c|c|c|c|c|c|c|c|c|c|c|}
\hline \multirow{3}{*}{$\begin{array}{l}\text { Quarters } \\
\text { before-after }\end{array}$} & \multicolumn{8}{|c|}{ "All individuals } & \multicolumn{2}{|c|}{ Employed only } & \multirow{2}{*}{\multicolumn{2}{|c|}{$\begin{array}{c}\text { Employed only Industry- } \\
\text { switchers } \\
\text { Hourly wage }\end{array}$}} \\
\hline & \multicolumn{2}{|c|}{ Monthly earnings } & \multicolumn{2}{|c|}{ Hours } & \multicolumn{2}{|c|}{ Hourly wage } & \multicolumn{2}{|c|}{ Employment } & \multicolumn{2}{|c|}{ Hourly wage } & & \\
\hline & $\mathrm{FE}$ & $\begin{array}{c}\text { PS } \\
\text { Matching }\end{array}$ & $\mathrm{FE}$ & $\begin{array}{c}\text { PS } \\
\text { Matching }\end{array}$ & FE & $\begin{array}{c}\text { PS } \\
\text { Matching }\end{array}$ & FE & $\begin{array}{c}\text { PS } \\
\text { Matching }\end{array}$ & $\mathrm{FE}$ & $\begin{array}{c}\text { PS } \\
\text { Matching }\end{array}$ & $\mathrm{FE}$ & $\begin{array}{c}\text { PS } \\
\text { Matching }\end{array}$ \\
\hline \multirow[t]{2}{*}{ bef_D_4 } & 693.873 & -222.20 & 1.420 & -0.35 & 4.784 & -2.21 & $0.060^{* * *}$ & 0.00 & 2.125 & -2.21 & 1.235 & -5.21 \\
\hline & (969.907) & (827.03) & $(0.951)$ & $(0.83)$ & $(4.523)$ & $(4.90)$ & $(0.016)$ & $(0.00)$ & (4.663) & $(4.90)$ & (5.449) & $(7.45)$ \\
\hline \multirow[t]{2}{*}{ bef_D_3 } & $1,009.654$ & 706.67 & 1.226 & -0.12 & 6.196 & 3.04 & $0.064^{* * *}$ & 0.00 & 3.389 & 3.18 & -3.110 & -6.16 \\
\hline & $(1,126.188)$ & (987.83) & $(0.968)$ & $(0.78)$ & (5.719) & ( 5.72$)$ & $(0.016)$ & $(0.00)$ & $(5.960)$ & ( 5.73$)$ & (5.383) & $(6.50)$ \\
\hline \multirow[t]{2}{*}{ bef_D_2 } & 1,399.180 & 60.84 & $1.624^{*}$ & -0.19 & 6.470 & -0.43 & $0.065^{* * *}$ & 0.00 & 3.437 & -0.52 & -0.769 & $-9.53 *$ \\
\hline & $(1,308.468)$ & $(905.86)$ & $(0.922)$ & $(0.77)$ & (6.103) & ( 5.24$)$ & $(0.017)$ & $(0.00)$ & (6.138) & ( 5.23$)$ & (6.912) & (5.76) \\
\hline \multirow[t]{2}{*}{ bef_D_1 } & $1,360.638$ & -60.34 & $2.037 * *$ & -0.15 & 6.620 & -2.31 & $0.080 * * *$ & 0.00 & 2.924 & -2.18 & -1.307 & -7.01 \\
\hline & $(1,253.779)$ & (878.74) & $(0.951)$ & $(0.80)$ & (5.931) & $(5.08)$ & $(0.017)$ & $(0.00)$ & $(6.027)$ & $(5.09)$ & $(6.421)$ & $(5.91)$ \\
\hline bef_D_0 & $\begin{array}{c}-962.046 \\
(855.414)\end{array}$ & $\begin{array}{c}-2094.69 * * * \\
(610.65)\end{array}$ & $\begin{array}{c}1.605 \\
(0.998)\end{array}$ & $\begin{array}{c}-0.46 \\
(0.88)\end{array}$ & $\begin{array}{c}-24.897 * * * \\
(4.854)\end{array}$ & $\begin{array}{c}-31.76 * * * \\
(3.69)\end{array}$ & $\begin{array}{c}-0.382 * * * \\
(0.029)\end{array}$ & $\begin{array}{c}-0.44 * * * \\
(0.03)\end{array}$ & $\begin{array}{l}-8.568^{*} \\
(5.097)\end{array}$ & $\begin{array}{c}-5.10 \\
(5.39)\end{array}$ & $\begin{array}{c}-12.774 * * \\
(5.837)\end{array}$ & $\begin{array}{l}-10.01 \\
(6.54)\end{array}$ \\
\hline \multirow[t]{2}{*}{ aft_D_1 } & $-3,508.651^{* * *}$ & $-4046.03^{* * *}$ & 0.103 & $-1.77^{*}$ & $-18.064^{* * *}$ & $-24.79 * * *$ & $-0.324 * * *$ & $-0.38 * * *$ & 1.424 & 6.53 & -2.745 & 5.55 \\
\hline & (979.532) & (703.30) & (1.101) & $(1.00)$ & (5.170) & ( 4.28) & $(0.029)$ & $(0.03)$ & (5.696) & ( 6.12$)$ & $(6.700)$ & $(7.46)$ \\
\hline \multirow[t]{2}{*}{ aft_D_2 } & $-2,599.361^{* *}$ & $-3994.91 * * *$ & $-2.186^{*}$ & $-4.59 * * *$ & $-13.571^{* * *}$ & $-23.51 * * *$ & $-0.269 * * *$ & $-0.32 * * *$ & 0.233 & -2.23 & -4.993 & -3.72 \\
\hline & $(1,038.356)$ & (730.96) & $(1.250)$ & ( 1.19$)$ & (5.174) & $(4.66)$ & (0.029) & $(0.03)$ & $(5.483)$ & ( 6.19$)$ & $(6.026)$ & $(6.81)$ \\
\hline \multirow[t]{2}{*}{ aft_D_3 } & $-2,492.274^{* *}$ & $-3770.34 * * *$ & $-5.502 * * *$ & $-7.76 * * *$ & $-9.857^{*}$ & $-20.28 * * *$ & $-0.233^{* * *}$ & $-0.28 * * *$ & 2.510 & -4.02 & -0.664 & -2.31 \\
\hline & $(1,054.401)$ & (747.54) & $(1.360)$ & $(1.30)$ & $(5.486)$ & ( 5.58$)$ & $(0.029)$ & $(0.03)$ & $(6.074)$ & ( 7.48$)$ & $(7.691)$ & $(9.85)$ \\
\hline \multirow[t]{2}{*}{ aft_D_4 } & $-2,089.118^{*}$ & $-3331.63^{* * *}$ & $-7.199 * * *$ & $-9.39 * * *$ & $-11.292 * *$ & $-22.22 * * *$ & $-0.207 * * *$ & $-0.25 * * *$ & -1.138 & -8.82 & -7.821 & -7.62 \\
\hline & $(1,081.424)$ & $(755.80)$ & (1.426) & $(1.41)$ & (5.374) & ( 4.85$)$ & $(0.029)$ & $(0.03)$ & (5.848) & ( 6.06$)$ & $(6.440)$ & $(6.06)$ \\
\hline \multirow[t]{2}{*}{ aft_D_5 } & $-2,260.956^{* *}$ & $-3526.02^{* * *}$ & $-6.091 * * *$ & $-8.60 * * *$ & $-10.594^{*}$ & $-21.36 * * *$ & $-0.194 * * *$ & $-0.25^{* * *}$ & -0.099 & -7.47 & -8.360 & -12.64 \\
\hline & $(1,106.777)$ & (793.59) & (1.398) & $(1.42)$ & (5.612) & ( 5.16$)$ & $(0.029)$ & $(0.03)$ & (6.166) & ( 6.47$)$ & (7.106) & $(7.70)$ \\
\hline \multirow[t]{2}{*}{ aft_D_6 } & $-2,340.053^{* *}$ & $-3380.51^{* * *}$ & $-5.873 * * *$ & $-8.69 * * *$ & $-10.423^{*}$ & $-18.97 * * *$ & $-0.174 * * *$ & $-0.22 * * *$ & -0.879 & -8.29 & -7.745 & -11.77 \\
\hline & $(1,116.215)$ & (796.35) & $(1.400)$ & $(1.46)$ & $(5.635)$ & ( 5.17) & $(0.029)$ & $(0.03)$ & $(6.140)$ & ( 6.57$)$ & (7.097) & $(7.78)$ \\
\hline \multirow[t]{2}{*}{ aft_D_7 } & $-1,997.477^{*}$ & $-3142.07 * * *$ & $-5.490 * * *$ & $-7.80 * * *$ & $-10.399^{*}$ & $-15.54 * * *$ & $-0.150 * * *$ & $-0.18 * * *$ & -0.888 & -7.01 & -6.686 & $-14.13^{*}$ \\
\hline & $(1,104.890)$ & (837.15) & (1.433) & $(1.51)$ & (5.508) & $(5.45)$ & $(0.029)$ & $(0.03)$ & $(6.107)$ & $(6.90)$ & $(7.216)$ & $(8.27)$ \\
\hline \multirow[t]{2}{*}{ aft_D_8 } & $-2,399.885 * *$ & $-3323.08^{* * *}$ & $-5.221 * * *$ & $-7.32 * * *$ & $-9.561^{*}$ & $-17.73^{* * *}$ & $-0.155^{* * *}$ & $-0.21 * * *$ & -0.414 & -5.67 & -7.140 & -8.25 \\
\hline & $(1,129.505)$ & (891.02) & (1.455) & $(1.60)$ & (5.607) & ( 6.00) & $(0.030)$ & $(0.03)$ & (6.466) & ( 7.19) & (7.963) & (7.94) \\
\hline \multirow[t]{2}{*}{ aft_D_9 } & $-2,429.344^{* *}$ & $-3026.65 * * *$ & $-5.123 * * *$ & $-6.75^{* * *}$ & $-11.291^{*}$ & $-19.33 * * *$ & $-0.147 * * *$ & $-0.19 * * *$ & -2.821 & -9.66 & -11.676 & -10.42 \\
\hline & $(1,179.366)$ & (998.08) & (1.507) & ( 1.73$)$ & $(5.760)$ & ( 6.37) & $(0.030)$ & $(0.03)$ & (6.648) & ( 7.63$)$ & $(7.640)$ & (7.53) \\
\hline \multirow[t]{2}{*}{ aft_D_10 } & $-2,063.739 *$ & $-2131.99 * *$ & $-3.556^{* *}$ & $-5.63 * * *$ & -9.372 & $-13.23^{* *}$ & $-0.140 * * *$ & $-0.18^{* * *}$ & -1.175 & -3.94 & -6.078 & -9.53 \\
\hline & $(1,193.022)$ & $(1054.02)$ & (1.547) & $(1.75)$ & (5.967) & ( 6.06) & $(0.031)$ & $(0.03)$ & $(6.855)$ & $(7.39)$ & (8.193) & $(9.45)$ \\
\hline \multirow[t]{2}{*}{ aft_D_11 } & $-2,513.577^{* *}$ & $-1884.68^{*}$ & -2.495 & $-4.96 * * *$ & $-13.655^{* *}$ & $-14.26 * *$ & $-0.155^{* * *}$ & $-0.19 * * *$ & -5.866 & -1.43 & -11.707 & -4.16 \\
\hline & $(1,208.026)$ & $(1091.05)$ & (1.558) & $(1.86)$ & (5.799) & $(6.16)$ & $(0.033)$ & $(0.04)$ & (6.901) & ( 7.10$)$ & (8.149) & $(8.30)$ \\
\hline
\end{tabular}




\begin{tabular}{|c|c|c|c|c|c|c|c|c|c|c|c|c|}
\hline \multirow{3}{*}{$\begin{array}{l}\text { Quarters } \\
\text { before-after }\end{array}$} & \multicolumn{8}{|c|}{ All individuals } & \multicolumn{2}{|c|}{ Employed only } & \multirow{2}{*}{\multicolumn{2}{|c|}{$\begin{array}{c}\text { Employed only Industry- } \\
\text { switchers } \\
\text { Hourly wage }\end{array}$}} \\
\hline & \multicolumn{2}{|c|}{ Monthly earnings } & \multicolumn{2}{|c|}{ Hours } & \multicolumn{2}{|c|}{ Hourly wage } & \multicolumn{2}{|c|}{ Employment } & \multicolumn{2}{|c|}{ Hourly wage } & & \\
\hline & $\mathrm{FE}$ & $\begin{array}{c}\text { PS } \\
\text { Matching }\end{array}$ & $\mathrm{FE}$ & $\begin{array}{c}\text { PS } \\
\text { Matching }\end{array}$ & $\mathrm{FE}$ & $\begin{array}{c}\text { PS } \\
\text { Matching }\end{array}$ & $\mathrm{FE}$ & $\begin{array}{c}\text { PS } \\
\text { Matching }\end{array}$ & $\mathrm{FE}$ & $\begin{array}{c}\text { PS } \\
\text { Matching }\end{array}$ & $\mathrm{FE}$ & $\begin{array}{c}\text { PS } \\
\text { Matching }\end{array}$ \\
\hline aft_D_12 & $\begin{array}{c}-2,666.033^{* *} \\
(1,272.251)\end{array}$ & $\begin{array}{l}-1327.01 \\
(1169.59)\end{array}$ & $\begin{array}{l}-2.798^{*} \\
(1.595)\end{array}$ & $\begin{array}{c}-5.18^{* * *} \\
(1.96)\end{array}$ & $\begin{array}{c}-12.739 * * \\
(6.050)\end{array}$ & $\begin{array}{l}-10.26 \\
(6.64)\end{array}$ & $\begin{array}{c}-0.151^{* * *} \\
(0.033)\end{array}$ & $\begin{array}{c}-0.19 * * * \\
(0.04)\end{array}$ & $\begin{array}{l}-2.956 \\
(7.085)\end{array}$ & $\begin{array}{c}3.92 \\
(7.71)\end{array}$ & $\begin{array}{l}-9.632 \\
(8.593)\end{array}$ & $\begin{array}{l}-1.98 \\
(8.88)\end{array}$ \\
\hline aft_D_13 & $\begin{array}{c}-2,874.242 * * \\
(1,343.653)\end{array}$ & $\begin{array}{l}-2240.34 * \\
(1266.51)\end{array}$ & $\begin{array}{c}-4.185 * * \\
(1.675)\end{array}$ & $\begin{array}{c}-6.64 * * * \\
(2.16)\end{array}$ & $\begin{array}{c}-11.258^{*} \\
(6.327)\end{array}$ & $\begin{array}{l}-12.77^{*} \\
(7.68)\end{array}$ & $\begin{array}{c}-0.140 * * * \\
(0.035)\end{array}$ & $\begin{array}{c}-0.19 * * * \\
(0.04)\end{array}$ & $\begin{array}{l}-2.391 \\
(7.662)\end{array}$ & $\begin{array}{l}1.62 \\
(8.88)\end{array}$ & $\begin{array}{l}-12.040 \\
(9.208)\end{array}$ & $\begin{array}{l}-9.33 \\
(9.59)\end{array}$ \\
\hline aft_D_14 & $\begin{array}{c}-2,888.156^{* *} \\
(1,354.347)\end{array}$ & $\begin{array}{l}-2123.24 \\
(1325.31)\end{array}$ & $\begin{array}{c}-4.380 * * \\
(1.743)\end{array}$ & $\begin{array}{c}-6.26 * * * \\
(2.37)\end{array}$ & $\begin{array}{l}-9.817 \\
(6.274)\end{array}$ & $\begin{array}{c}-8.79 \\
(7.81)\end{array}$ & $\begin{array}{c}-0.129 * * * \\
(0.038)\end{array}$ & $\begin{array}{c}-0.18^{* * *} \\
(0.04)\end{array}$ & $\begin{array}{l}-2.330 \\
(8.040)\end{array}$ & $\begin{array}{c}5.64 \\
(8.79)\end{array}$ & $\begin{array}{l}-12.719 \\
(9.635)\end{array}$ & $\begin{array}{l}-4.14 \\
(9.57)\end{array}$ \\
\hline aft_D_15 & $\begin{array}{c}-3,227.265^{* *} \\
(1,479.495)\end{array}$ & $\begin{array}{l}-1117.56 \\
(1439.03)\end{array}$ & $\begin{array}{c}-5.003 * * \\
(1.946)\end{array}$ & $\begin{array}{l}-6.32 * * \\
(2.81)\end{array}$ & $\begin{array}{l}-8.964 \\
(7.081)\end{array}$ & $\begin{array}{c}-4.24 \\
(9.88)\end{array}$ & $\begin{array}{c}-0.130 * * * \\
(0.043)\end{array}$ & $\begin{array}{c}-0.18^{* * *} \\
(0.05)\end{array}$ & $\begin{array}{l}-1.209 \\
(9.281)\end{array}$ & $\begin{array}{l}5.13 \\
(11.97)\end{array}$ & $\begin{array}{l}-16.001 \\
(10.650)\end{array}$ & $\begin{array}{c}-6.37 \\
\left(\begin{array}{c}11.74 \\
)\end{array}\right)\end{array}$ \\
\hline aft_D_16 & $\begin{array}{c}-3,853.777^{* *} \\
(1,643.753)\end{array}$ & $\begin{array}{l}-1250.66 \\
(1492.18)\end{array}$ & $\begin{array}{c}-4.478 * * \\
(2.088)\end{array}$ & $\begin{array}{c}-8.36 * * * \\
(3.54)\end{array}$ & $\begin{array}{c}-14.509 * * \\
(6.803)\end{array}$ & $\begin{array}{l}-4.91 \\
(8.62)\end{array}$ & $\begin{array}{c}-0.147 * * * \\
(0.048)\end{array}$ & $\begin{array}{c}-0.19 * * * \\
(0.07)\end{array}$ & $\begin{array}{l}-9.000 \\
(9.412)\end{array}$ & $\begin{array}{c}2.93 \\
(9.83)\end{array}$ & $\begin{array}{l}-19.976 \\
(12.596)\end{array}$ & $\begin{array}{c}-1.94 \\
\left(\begin{array}{c}11.85 \\
)\end{array}\right)\end{array}$ \\
\hline Constant & $\begin{array}{c}10,781.652 * * * \\
(133.988)\end{array}$ & & $\begin{array}{c}42.015^{* * *} \\
(0.126)\end{array}$ & & $\begin{array}{c}61.527 * * * \\
(0.749)\end{array}$ & & $\begin{array}{c}0.986 * * * \\
(0.003)\end{array}$ & & $\begin{array}{c}63.467 * * * \\
(0.653)\end{array}$ & & $\begin{array}{c}63.772 * * * \\
(0.617)\end{array}$ & \\
\hline Obs. & 79354 & & 84176 & & 78063 & & 85978 & & 72152 & & 68406 & \\
\hline
\end{tabular}

Notes: Robust (corrected for matching) standard errors in parentheses. * significant at 10\%; ** significant at 5\%; *** significant at $1 \%$. 
Table 3: The effect of displacement on additional labor market outcomes

\begin{tabular}{|c|c|c|c|c|c|c|c|c|}
\hline \multirow{2}{*}{$\begin{array}{l}\text { Quarters } \\
\text { before- } \\
\text { after }\end{array}$} & \multicolumn{2}{|c|}{$\begin{array}{c}\text { Permanent written } \\
\text { contract }\end{array}$} & \multicolumn{2}{|c|}{$\begin{array}{l}\text { Oral contract without } \\
\text { written agreement }\end{array}$} & \multicolumn{2}{|c|}{ "Number of benefits } & \multicolumn{2}{|c|}{$\begin{array}{c}\text { Monetary value of } \\
\text { benefits }\end{array}$} \\
\hline & $\mathrm{FE}$ & $\begin{array}{c}\text { PS } \\
\text { Matching }\end{array}$ & $\mathrm{FE}$ & $\begin{array}{c}\text { PS } \\
\text { Matching }\end{array}$ & $\mathrm{FE}$ & $\begin{array}{c}\text { PS } \\
\text { Matching }\end{array}$ & $\mathrm{FE}$ & $\begin{array}{c}\text { PS } \\
\text { Matching }\end{array}$ \\
\hline bef_D_4 & $\begin{array}{l}-0.062^{*} \\
(0.034)\end{array}$ & $\begin{array}{l}-0.01 \\
(0.02)\end{array}$ & $\begin{array}{l}0.030 * \\
(0.018)\end{array}$ & $\begin{array}{c}0.01 \\
(0.02)\end{array}$ & $\begin{array}{c}-0.253^{* *} \\
(0.121)\end{array}$ & $\begin{array}{c}-0.40 * * * \\
(0.14)\end{array}$ & $\begin{array}{l}-273.159 \\
(211.570)\end{array}$ & $\begin{array}{l}-524.52^{*} \\
(274.36)\end{array}$ \\
\hline bef_D_3 & $\begin{array}{l}-0.051 \\
(0.033)\end{array}$ & $\begin{array}{l}-0.02 \\
(0.02)\end{array}$ & $\begin{array}{l}0.031^{*} \\
(0.018)\end{array}$ & $\begin{array}{c}0.02 \\
(0.01)\end{array}$ & $\begin{array}{l}-0.239 * \\
(0.123)\end{array}$ & $\begin{array}{c}-0.45^{* * *} \\
(0.13)\end{array}$ & $\begin{array}{c}119.539 \\
(520.780)\end{array}$ & $\begin{array}{c}-0.27 \\
(612.54)\end{array}$ \\
\hline bef_D_2 & $\begin{array}{l}-0.052 \\
(0.034)\end{array}$ & $\begin{array}{l}-0.02 \\
(0.02)\end{array}$ & $\begin{array}{c}0.025 \\
(0.017)\end{array}$ & $\begin{array}{c}0.02 \\
(0.01)\end{array}$ & $\begin{array}{c}-0.254^{* *} \\
(0.124)\end{array}$ & $\begin{array}{c}-0.45 * * * \\
(0.13)\end{array}$ & $\begin{array}{c}54.117 \\
(490.949)\end{array}$ & $\begin{array}{c}-40.01 \\
(560.17)\end{array}$ \\
\hline bef_D_1 & $\begin{array}{c}-0.052 \\
(0.034)\end{array}$ & $\begin{array}{l}-0.02 \\
(0.02)\end{array}$ & $\begin{array}{c}0.025 \\
(0.018)\end{array}$ & $\begin{array}{c}0.01 \\
(0.01)\end{array}$ & $\begin{array}{l}-0.230 * \\
(0.126)\end{array}$ & $\begin{array}{c}-0.43 * * * \\
(0.12)\end{array}$ & $\begin{array}{c}-6.306 \\
(477.998)\end{array}$ & $\begin{array}{l}-197.42 \\
(523.16)\end{array}$ \\
\hline bef_D_0 & $\begin{array}{c}-0.139 * * * \\
(0.041)\end{array}$ & $\begin{array}{c}-0.11 * * * \\
(0.03)\end{array}$ & $\begin{array}{c}0.053 * * \\
(0.021)\end{array}$ & $\begin{array}{l}0.04^{* *} \\
(0.02)\end{array}$ & $\begin{array}{c}-0.314^{* *} \\
(0.156)\end{array}$ & $\begin{array}{c}-0.48 * * * \\
(0.18)\end{array}$ & $\begin{array}{l}-522.039 * \\
(270.367)\end{array}$ & $\begin{array}{l}-343.17 \\
(321.47)\end{array}$ \\
\hline aft_D_1 & $\begin{array}{c}-0.151 * * * \\
(0.042)\end{array}$ & $\begin{array}{c}-0.13 * * * \\
(0.03)\end{array}$ & $\begin{array}{c}0.057 * * * \\
(0.021)\end{array}$ & $\begin{array}{l}0.04^{*} \\
(0.02)\end{array}$ & $\begin{array}{c}-0.569 * * * \\
(0.168)\end{array}$ & $\begin{array}{c}-0.78 * * * \\
(0.17)\end{array}$ & $\begin{array}{l}-316.077 \\
(359.215)\end{array}$ & $\begin{array}{c}123.23 \\
(383.41)\end{array}$ \\
\hline aft_D_2 & $\begin{array}{c}-0.141 * * * \\
(0.041)\end{array}$ & $\begin{array}{c}-0.09 * * * \\
(0.03)\end{array}$ & $\begin{array}{c}0.066^{* * *} * \\
(0.023)\end{array}$ & $\begin{array}{l}0.04^{*} \\
(0.02)\end{array}$ & $\begin{array}{c}-0.629 * * * \\
(0.160)\end{array}$ & $\begin{array}{c}-0.74 * * * \\
(0.17)\end{array}$ & $\begin{array}{l}-387.035 \\
(351.619)\end{array}$ & $\begin{array}{c}-122.94 \\
(359.66)\end{array}$ \\
\hline aft_D_3 & $\begin{array}{c}-0.156 * * * \\
(0.042)\end{array}$ & $\begin{array}{c}-0.12 * * * \\
(0.03)\end{array}$ & $\begin{array}{c}0.068 * * * \\
(0.023)\end{array}$ & $\begin{array}{c}0.05^{* * *} \\
(0.02)\end{array}$ & $\begin{array}{c}-0.598 * * * \\
(0.162)\end{array}$ & $\begin{array}{c}-0.67 * * * \\
(0.17)\end{array}$ & $\begin{array}{l}-488.811 \\
(349.147)\end{array}$ & $\begin{array}{l}-267.33 \\
(302.33)\end{array}$ \\
\hline aft_D_4 & $\begin{array}{c}-0.132 * * * \\
(0.042)\end{array}$ & $\begin{array}{c}-0.11 * * * \\
(0.03)\end{array}$ & $\begin{array}{c}0.056 * * \\
(0.024)\end{array}$ & $\begin{array}{c}0.05^{* * *} \\
(0.02)\end{array}$ & $\begin{array}{c}-0.537 * * * \\
(0.165)\end{array}$ & $\begin{array}{c}-0.75 * * * \\
(0.17)\end{array}$ & $\begin{array}{l}-287.500 \\
(361.740)\end{array}$ & $\begin{array}{l}-153.03 \\
(294.87)\end{array}$ \\
\hline aft_D_5 & $\begin{array}{c}-0.141^{* * *} \\
(0.043)\end{array}$ & $\begin{array}{c}-0.12 * * * \\
(0.03)\end{array}$ & $\begin{array}{c}0.066 * * * \\
(0.025)\end{array}$ & $\begin{array}{c}0.07^{* * *} \\
(0.02)\end{array}$ & $\begin{array}{c}-0.570 * * * \\
(0.168)\end{array}$ & $\begin{array}{c}-0.83 * * * \\
(0.17)\end{array}$ & $\begin{array}{l}-209.595 \\
(348.524)\end{array}$ & $\begin{array}{l}-214.89 \\
(309.80)\end{array}$ \\
\hline aft_D_6 & $\begin{array}{c}-0.129 * * * \\
(0.042)\end{array}$ & $\begin{array}{c}-0.08 * * * \\
(0.03)\end{array}$ & $\begin{array}{c}0.064 * * * \\
(0.025)\end{array}$ & $\begin{array}{c}0.05^{* * *} \\
(0.02)\end{array}$ & $\begin{array}{c}-0.532 * * * \\
(0.170)\end{array}$ & $\begin{array}{c}-0.77 * * * \\
(0.17)\end{array}$ & $\begin{array}{l}-106.431 \\
(350.541)\end{array}$ & $\begin{array}{c}-9.42 \\
(315.53)\end{array}$ \\
\hline aft_D_7 & $\begin{array}{c}-0.122 * * * \\
(0.043)\end{array}$ & $\begin{array}{c}-0.08 * * * \\
(0.03)\end{array}$ & $\begin{array}{c}0.067 * * * \\
(0.026)\end{array}$ & $\begin{array}{c}0.06 * * * \\
(0.02)\end{array}$ & $\begin{array}{c}-0.512^{* * *} \\
(0.167)\end{array}$ & $\begin{array}{c}-0.80 * * * \\
(0.18)\end{array}$ & $\begin{array}{l}-189.679 \\
(312.033)\end{array}$ & $\begin{array}{c}-37.02 \\
(290.80)\end{array}$ \\
\hline aft_D_8 & $\begin{array}{c}-0.115 * * * \\
(0.042)\end{array}$ & $\begin{array}{c}-0.09 * * * \\
(0.04)\end{array}$ & $\begin{array}{c}0.062 * * \\
(0.025)\end{array}$ & $\begin{array}{c}0.05 * * \\
(0.02)\end{array}$ & $\begin{array}{c}-0.524 * * * \\
(0.162)\end{array}$ & $\begin{array}{c}-0.67 * * * \\
(0.19)\end{array}$ & $\begin{array}{l}-110.780 \\
(325.431)\end{array}$ & $\begin{array}{c}183.74 \\
(320.41)\end{array}$ \\
\hline aft_D_9 & $\begin{array}{c}-0.105^{* *} \\
(0.042)\end{array}$ & $\begin{array}{l}-0.06^{*} \\
(0.04)\end{array}$ & $\begin{array}{c}0.063 * * * \\
(0.025)\end{array}$ & $\begin{array}{c}0.06^{* * *} \\
(0.02)\end{array}$ & $\begin{array}{c}-0.525 * * * \\
(0.163)\end{array}$ & $\begin{array}{c}-0.85 * * * \\
(0.20)\end{array}$ & $\begin{array}{c}-66.028 \\
(326.598)\end{array}$ & $\begin{array}{c}116.23 \\
(336.53)\end{array}$ \\
\hline aft_D_10 & $\begin{array}{c}-0.120 * * * \\
(0.042)\end{array}$ & $\begin{array}{c}-0.08 * * \\
(0.04)\end{array}$ & $\begin{array}{c}0.060 * * \\
(0.024)\end{array}$ & $\begin{array}{c}0.05^{* *} \\
(0.02)\end{array}$ & $\begin{array}{c}-0.565 * * * \\
(0.161)\end{array}$ & $\begin{array}{c}-1.01 * * * \\
(0.20)\end{array}$ & $\begin{array}{c}125.622 \\
(416.122)\end{array}$ & $\begin{array}{c}397.07 \\
(479.94)\end{array}$ \\
\hline aft_D_11 & $\begin{array}{c}-0.114^{* * *} \\
(0.043)\end{array}$ & $\begin{array}{c}-0.08 * * \\
(0.04)\end{array}$ & $\begin{array}{c}0.066^{* * *} \\
(0.025)\end{array}$ & $\begin{array}{c}0.05^{* *} \\
(0.02)\end{array}$ & $\begin{array}{c}-0.583 * * * \\
(0.167)\end{array}$ & $\begin{array}{c}-1.06 * * * \\
(0.21)\end{array}$ & $\begin{array}{l}-135.312 \\
(346.574)\end{array}$ & $\begin{array}{c}136.25 \\
(421.24)\end{array}$ \\
\hline aft_D_12 & $\begin{array}{c}-0.116^{* * *} \\
(0.044)\end{array}$ & $\begin{array}{c}-0.10^{* *} \\
(0.04)\end{array}$ & $\begin{array}{c}0.068 * * * \\
(0.025)\end{array}$ & $\begin{array}{c}0.06^{* * *} \\
(0.03)\end{array}$ & $\begin{array}{c}-0.546 * * * \\
(0.173)\end{array}$ & $\begin{array}{c}-0.94 * * * \\
(0.23)\end{array}$ & $\begin{array}{c}-25.303 \\
(355.977)\end{array}$ & $\begin{array}{c}609.67 \\
(464.42)\end{array}$ \\
\hline aft_D_13 & $\begin{array}{c}-0.156 * * * \\
(0.045)\end{array}$ & $\begin{array}{c}-0.16^{* * * *} \\
(0.05)\end{array}$ & $\begin{array}{c}0.089 * * * \\
(0.026)\end{array}$ & $\begin{array}{c}0.10^{* * *} \\
(0.03)\end{array}$ & $\begin{array}{c}-0.571 \text { *** } \\
(0.173)\end{array}$ & $\begin{array}{c}-0.92 * * * \\
(0.24)\end{array}$ & $\begin{array}{c}-45.706 \\
(361.220)\end{array}$ & $\begin{array}{c}640.65 \\
(477.06)\end{array}$ \\
\hline aft_D_14 & $\begin{array}{c}-0.171 * * * \\
(0.047)\end{array}$ & $\begin{array}{c}-0.18^{* * *} \\
(0.05)\end{array}$ & $\begin{array}{c}0.088 * * * \\
(0.026)\end{array}$ & $\begin{array}{c}0.10^{* * *} \\
(0.03)\end{array}$ & $\begin{array}{c}-0.526 * * * \\
(0.178)\end{array}$ & $\begin{array}{c}-0.91 * * * \\
(0.24)\end{array}$ & $\begin{array}{c}-32.632 \\
(386.961)\end{array}$ & $\begin{array}{c}562.89 \\
(487.57)\end{array}$ \\
\hline aft_D_15 & $\begin{array}{c}-0.165 * * * \\
(0.050)\end{array}$ & $\begin{array}{c}-0.21 * * * \\
(0.06)\end{array}$ & $\begin{array}{c}0.075^{* * *} \\
(0.027)\end{array}$ & $\begin{array}{c}0.08 * * \\
(0.04)\end{array}$ & $\begin{array}{c}-0.512^{* * *} \\
(0.191)\end{array}$ & $\begin{array}{c}-1.03^{* * * *} \\
(0.30)\end{array}$ & $\begin{array}{c}-26.070 \\
(418.504)\end{array}$ & $\begin{array}{c}498.65 \\
(590.62)\end{array}$ \\
\hline aft_D_16 & $\begin{array}{c}-0.207 * * * \\
(0.055)\end{array}$ & $\begin{array}{c}-0.20 * * * \\
(0.07)\end{array}$ & $\begin{array}{c}0.085^{* * *} * \\
(0.028)\end{array}$ & $\begin{array}{c}0.10^{* * *} \\
(0.04)\end{array}$ & $\begin{array}{c}-0.509 * * \\
(0.219)\end{array}$ & $\begin{array}{c}-0.82^{* *} \\
(0.37)\end{array}$ & $\begin{array}{c}-88.002 \\
(493.210)\end{array}$ & $\begin{array}{c}688.09 \\
(738.46)\end{array}$ \\
\hline Constant & $\begin{array}{c}0.917 * * * \\
(0.003)\end{array}$ & & $\begin{array}{c}0.015^{* * *} \\
(0.002)\end{array}$ & & $\begin{array}{c}3.282^{* * *} \\
(0.013)\end{array}$ & & $\begin{array}{c}2,460.5^{* * *} \\
(32.916)\end{array}$ & \\
\hline Obs. & 80067 & & 80067 & & 79867 & & 80067 & \\
\hline
\end{tabular}

Notes: Robust (corrected for matching) standard errors in parentheses. * significant at $10 \%$; ${ }^{* *}$ significant at $5 \%$; *** significant at $1 \%$.

NOTE: in the pscore estimation there is a dummy for each type of benefit. Although dummies are balanced this is not sufficient to balance the number of benefit in the pre-displacement period (zero is out of the confidence interval). 
Table 4a: Robustness checks: Estimates from matching procedure

\begin{tabular}{|c|c|c|c|c|c|c|c|}
\hline \multirow[b]{2}{*}{$\begin{array}{l}\text { Quartes } \\
\text { before / after }\end{array}$} & \multicolumn{2}{|c|}{$\begin{array}{l}\text { Include U benefits instead of } \\
\text { zeroes }\end{array}$} & \multicolumn{5}{|c|}{$\begin{array}{c}\text { Displaced group excludes “dismissal initiated by employer” and “personnel } \\
\text { reduction” }\end{array}$} \\
\hline & $\begin{array}{c}\text { Monthly } \\
\text { earnings+ } \\
\text { initial U ben. }\end{array}$ & $\begin{array}{c}\text { Monthly } \\
\text { earnings+ } \\
\text { final U ben. }\end{array}$ & $\begin{array}{l}\text { Monthly } \\
\text { earnings }\end{array}$ & Hours & $\begin{array}{c}\text { Hourly } \\
\text { wage: all }\end{array}$ & Employment & $\begin{array}{c}\text { Hourly } \\
\text { wage: re- } \\
\text { employed } \\
\text { only }\end{array}$ \\
\hline \multirow[t]{2}{*}{-4} & -222.20 & -222.20 & -828.45 & -0.29 & -2.61 & 0.00 & -2.98 \\
\hline & (827.03) & (827.03) & (1026.19) & $(0.86)$ & (5.61) & $(0.00)$ & $(5.60)$ \\
\hline \multirow[t]{2}{*}{-3} & 706.67 & 706.67 & -307.08 & -0.62 & -0.21 & 0.00 & -0.36 \\
\hline & (987.83) & (987.83) & (1259.42) & $(0.87)$ & (6.90) & $(0.00)$ & (6.91) \\
\hline \multirow[t]{2}{*}{-2} & 60.84 & 60.84 & -426.35 & 0.03 & -4.34 & 0.00 & -4.15 \\
\hline & (905.86) & (905.86) & (1100.82) & $(0.78)$ & (6.55) & $(0.00)$ & (6.56) \\
\hline \multirow[t]{2}{*}{-1} & -60.34 & -60.34 & -851.86 & 0.27 & -5.81 & 0.00 & -5.81 \\
\hline & (878.74) & (878.74) & (1120.79) & $(0.76)$ & (6.57) & $(0.00)$ & (6.57) \\
\hline \multirow[t]{2}{*}{0} & $-1855.59 * * *$ & $-1916.91 * * *$ & $-2445.26 * * *$ & -0.95 & $-32.65 * * *$ & $-0.42 * * *$ & -11.80 \\
\hline & (609.02) & (609.65) & (818.85) & $(0.88)$ & (4.57) & $(0.03)$ & (8.68) \\
\hline \multirow[t]{2}{*}{1} & $-3800.77 * * *$ & $-3868.93 * * *$ & $-4141.55 * * *$ & -1.48 & $-23.54 * * *$ & $-0.34 * * *$ & 5.21 \\
\hline & (698.58) & (699.84) & (853.43) & (0.99) & (4.75) & (0.03) & (6.76) \\
\hline \multirow[t]{2}{*}{2} & $-3831.01 * * *$ & $-3867.75 * * *$ & $-3698.72 * * *$ & $-3.84 * * *$ & $-18.19 * * *$ & $-0.28 * * *$ & 3.84 \\
\hline & (727.12) & (727.98) & (878.18) & (1.20) & (4.94) & (0.03) & (6.50) \\
\hline \multirow[t]{2}{*}{3} & $-3652.97 * * *$ & $-3682.35 * * *$ & $-2963.60 * * *$ & $-6.39 * * *$ & $-11.94^{* *}$ & $-0.22 * * *$ & 4.73 \\
\hline & (744.69) & (745.34) & (894.84) & (1.32) & (6.07) & $(0.03)$ & (7.97) \\
\hline \multirow[t]{2}{*}{4} & $-3242.17 * * *$ & $-3264.65 * * *$ & $-2565.40 * * *$ & $-7.62 * * *$ & $-14.74 * * *$ & $-0.20 * * *$ & -1.46 \\
\hline & (753.34) & (754.05) & (930.09) & (1.43) & (5.17) & $(0.03)$ & (6.31) \\
\hline \multirow[t]{2}{*}{5} & $-3435.41 * * *$ & $-3458.78 * * *$ & $-2803.83 * * *$ & $-6.42 * * *$ & $-13.78 * * *$ & $-0.18 * * *$ & -2.88 \\
\hline & (790.90) & (791.62) & (999.32) & (1.44) & (5.80) & $(0.03)$ & (7.10) \\
\hline \multirow[t]{2}{*}{6} & $-3350.99 * * *$ & $-3354.99 * * *$ & $-3046.80 * * *$ & $-6.08 * * *$ & $-14.49 * * *$ & $-0.15^{* * *}$ & -6.44 \\
\hline & (794.22) & (794.20) & (1018.29) & (1.52) & $(6.01)$ & $(0.03)$ & (7.78) \\
\hline \multirow[t]{2}{*}{7} & $-3127.81 * * *$ & $-3129.45 * * *$ & $-2864.58 * * *$ & $-5.26 * * *$ & $-13.44^{* *}$ & $-0.15^{* * *}$ & -0.05 \\
\hline & (836.14) & (836.18) & (1038.66) & (1.62) & (6.18) & $(0.03)$ & (7.15) \\
\hline \multirow[t]{2}{*}{8} & $-3330.08 * * *$ & $-3335.78 * * *$ & $-2919.29 * * *$ & $-4.03 * * *$ & $-13.43^{* *}$ & $-0.14 * * *$ & -0.81 \\
\hline & (889.82) & (889.75) & (1079.82) & (1.69) & (6.33) & (0.03) & (7.30) \\
\hline \multirow[t]{2}{*}{9} & $-3034.26 * * *$ & $-3040.25 * * *$ & $-2929.89 * * *$ & $-4.02 * *$ & $-15.06 * *$ & $-0.15^{* * *}$ & -2.54 \\
\hline & (996.82) & (996.74) & (1187.64) & (1.77) & (6.63) & $(0.04)$ & (7.56) \\
\hline \multirow[t]{2}{*}{10} & $-2142.22 * *$ & $-2148.42^{* *}$ & -1784.27 & $-3.41^{*}$ & -9.21 & $-0.15^{* * *}$ & 2.68 \\
\hline & (1052.53) & (1052.45) & (1219.66) & (1.78) & (6.65) & $(0.04)$ & (7.48) \\
\hline \multirow[t]{2}{*}{11} & $-1893.84 *$ & $-1900.57^{*}$ & $-2697.68 * *$ & -2.96 & $-15.92 * *$ & $-0.18 * * *$ & -3.48 \\
\hline & (1089.46) & (1089.37) & (1279.54) & (1.92) & (6.85) & $(0.04)$ & (7.94) \\
\hline \multirow[t]{2}{*}{12} & -1342.01 & -1350.80 & $-2627.10 *$ & $-3.85 *$ & -11.01 & $-0.18 * * *$ & 0.53 \\
\hline & (1167.96) & (1167.92) & (1413.73) & $(2.02)$ & $(7.55)$ & $(0.04)$ & $(8.70)$ \\
\hline \multirow[t]{2}{*}{13} & $-2266.39 *$ & $-2272.47^{*}$ & $-3293.17 * *$ & $-4.72 * *$ & $-16.15^{*}$ & $-0.16^{* * *}$ & -5.46 \\
\hline & (1264.98) & (1264.70) & (1478.96) & (2.16) & (8.51) & $(0.04)$ & (9.78) \\
\hline \multirow[t]{2}{*}{14} & -2151.79 & -2158.45 & $-3963.53 * * *$ & $-5.30 * * *$ & $-15.55^{*}$ & $-0.17 * * *$ & -6.44 \\
\hline & $(1323.50)$ & (1323.17) & (1537.71) & $(2.27)$ & $(8.51)$ & $(0.05)$ & (9.68) \\
\hline \multirow[t]{2}{*}{15} & -1131.71 & -1139.75 & $-3446.58 * *$ & $-4.88^{*}$ & -12.85 & $-0.15 * * *$ & -0.01 \\
\hline & (1435.31) & (1434.87) & $(1757.40)$ & $(2.82)$ & (11.14) & $(0.06)$ & (13.25) \\
\hline 16 & -1298.27 & -1309.38 & $-3190.65^{*}$ & -3.67 & -14.39 & $-0.17 * * *$ & -8.68 \\
\hline & (1487.63) & (1486.80) & (1864.66) & (3.30) & (9.91) & $(0.07)$ & $(11.26)$ \\
\hline
\end{tabular}


Table 4b (continued): Robustness checks: Estimates from matching procedure

\begin{tabular}{|c|c|c|c|c|c|c|c|c|}
\hline \multirow[b]{2}{*}{$\begin{array}{l}\text { Quartes } \\
\text { before / } \\
\text { after }\end{array}$} & \multicolumn{4}{|c|}{$\begin{array}{l}\text { Displaced workers who did not receive any prior } \\
\text { notification }\end{array}$} & \multicolumn{4}{|c|}{ No quitters in the control group } \\
\hline & $\begin{array}{l}\text { Monthly } \\
\text { earnings }\end{array}$ & Hours & Employment & $\begin{array}{c}\text { Hourly } \\
\text { wage re- } \\
\text { employed }\end{array}$ & $\begin{array}{l}\text { Monthly } \\
\text { earnings }\end{array}$ & Hours & Employment & $\begin{array}{c}\text { Hourly } \\
\text { wage re- } \\
\text { employed }\end{array}$ \\
\hline-4 & $\begin{array}{c}-608.14 \\
(1006.62)\end{array}$ & $\begin{array}{l}-0.92 \\
(1.06)\end{array}$ & $\begin{array}{c}0.00 \\
(0.00)\end{array}$ & $\begin{array}{l}-1.98 \\
(5.43)\end{array}$ & $\begin{array}{l}-78.50 \\
(792.68)\end{array}$ & $\begin{array}{l}-0.92 \\
(0.89)\end{array}$ & $\begin{array}{c}0.00 \\
(0.00)\end{array}$ & $\begin{array}{c}0.81 \\
(4.31)\end{array}$ \\
\hline-3 & $\begin{array}{c}220.79 \\
(1239.18)\end{array}$ & $\begin{array}{l}-0.75 \\
(0.98)\end{array}$ & $\begin{array}{c}0.00 \\
(0.00)\end{array}$ & $\begin{array}{c}1.54 \\
(6.94)\end{array}$ & $\begin{array}{c}0.70 \\
(998.40)\end{array}$ & $\begin{array}{l}-0.52 \\
(0.84)\end{array}$ & $\begin{array}{c}0.00 \\
(0.00)\end{array}$ & $\begin{array}{c}0.56 \\
(5.52)\end{array}$ \\
\hline-2 & $\begin{array}{l}-336.39 \\
(1127.21)\end{array}$ & $\begin{array}{l}-1.32 \\
(1.03)\end{array}$ & $\begin{array}{c}0.00 \\
(0.00)\end{array}$ & $\begin{array}{l}-1.14 \\
(6.38)\end{array}$ & $\begin{array}{l}-479.86 \\
(919.70)\end{array}$ & $\begin{array}{l}-0.50 \\
(0.79)\end{array}$ & $\begin{array}{c}0.00 \\
(0.00)\end{array}$ & $\begin{array}{l}-1.16 \\
(5.01)\end{array}$ \\
\hline-1 & $\begin{array}{c}-489.14 \\
(1104.01)\end{array}$ & $\begin{array}{l}-0.63 \\
(0.98)\end{array}$ & $\begin{array}{c}0.00 \\
(0.00)\end{array}$ & $\begin{array}{l}-1.96 \\
(6.20)\end{array}$ & $\begin{array}{c}-422.93 \\
(893.50)\end{array}$ & $\begin{array}{l}-0.09 \\
(0.75)\end{array}$ & $\begin{array}{c}0.00 \\
(0.00)\end{array}$ & $\begin{array}{l}-1.60 \\
(4.91)\end{array}$ \\
\hline 0 & $\begin{array}{c}-1924.34 * * * \\
(730.23)\end{array}$ & $\begin{array}{l}-0.96 \\
(1.07)\end{array}$ & $\begin{array}{c}-0.45 * * * \\
(0.03)\end{array}$ & $\begin{array}{c}2.77 \\
(5.60)\end{array}$ & $\begin{array}{c}-2135.92 * * * \\
(624.51)\end{array}$ & $\begin{array}{l}-0.58 \\
(0.78)\end{array}$ & $\begin{array}{c}-0.44 * * * \\
(0.03)\end{array}$ & $\begin{array}{l}-3.00 \\
(5.09)\end{array}$ \\
\hline 1 & $\begin{array}{c}-4542.44 * * * \\
(806.42)\end{array}$ & $\begin{array}{l}-1.88 \\
(1.19)\end{array}$ & $\begin{array}{c}-0.36 * * * \\
(0.03)\end{array}$ & $\begin{array}{c}4.71 \\
(5.72)\end{array}$ & $\begin{array}{c}-4225.77 * * * \\
(713.21)\end{array}$ & $\begin{array}{c}-2.13^{* *} \\
(0.92)\end{array}$ & $\begin{array}{c}-0.38 * * * \\
(0.03)\end{array}$ & $\begin{array}{c}4.94 \\
(6.00)\end{array}$ \\
\hline 2 & $\begin{array}{c}-4181.87 * * * \\
(843.80)\end{array}$ & $\begin{array}{c}-4.42 * * * \\
(1.32)\end{array}$ & $\begin{array}{c}-0.32 * * * \\
(0.03)\end{array}$ & $\begin{array}{l}-1.21 \\
(5.84)\end{array}$ & $\begin{array}{c}-3829.82^{* * *} \\
(745.10)\end{array}$ & $\begin{array}{c}-4.95 * * * \\
(1.13)\end{array}$ & $\begin{array}{c}-0.33 * * * \\
(0.03)\end{array}$ & $\begin{array}{l}-0.26 \\
(5.70)\end{array}$ \\
\hline 3 & $\begin{array}{c}-3740.82 * * * \\
(863.47)\end{array}$ & $\begin{array}{c}-7.57 * * * \\
(1.48)\end{array}$ & $\begin{array}{c}-0.26 * * * \\
(0.03)\end{array}$ & $\begin{array}{c}4.91 \\
(7.94)\end{array}$ & $\begin{array}{c}-3806.95 * * * \\
(788.69)\end{array}$ & $\begin{array}{c}-7.57 * * * \\
(1.27)\end{array}$ & $\begin{array}{c}-0.28 * * * \\
(0.03)\end{array}$ & $\begin{array}{c}2.46 \\
(7.07)\end{array}$ \\
\hline 4 & $\begin{array}{c}-2937.66 * * * \\
(875.21)\end{array}$ & $\begin{array}{c}-8.48 * * * \\
(1.62)\end{array}$ & $\begin{array}{c}-0.24 * * * \\
(0.03)\end{array}$ & $\begin{array}{l}-1.60 \\
(5.81)\end{array}$ & $\begin{array}{c}-3230.36 * * * \\
(815.48)\end{array}$ & $\begin{array}{c}-9.04 * * * \\
(1.37)\end{array}$ & $\begin{array}{c}-0.26 * * * \\
(0.03)\end{array}$ & $\begin{array}{l}-2.72 \\
(5.60)\end{array}$ \\
\hline 5 & $\begin{array}{c}-3501.92 * * * \\
(918.96)\end{array}$ & $\begin{array}{c}-7.09 * * * \\
(1.59)\end{array}$ & $\begin{array}{c}-0.22 * * * \\
(0.03)\end{array}$ & $\begin{array}{l}-2.20 \\
(6.56)\end{array}$ & $\begin{array}{c}-3227.65^{* * *} \\
(848.47)\end{array}$ & $\begin{array}{c}-7.76^{* * *} \\
(1.36)\end{array}$ & $\begin{array}{c}-0.25^{* * *} \\
(0.03)\end{array}$ & $\begin{array}{l}-0.41 \\
(6.02)\end{array}$ \\
\hline 6 & $\begin{array}{c}-3829.62 * * * \\
(957.71)\end{array}$ & $\begin{array}{c}-7.21 * * * \\
(1.65)\end{array}$ & $\begin{array}{c}-0.21 * * * \\
(0.03)\end{array}$ & $\begin{array}{l}-6.74 \\
(7.03)\end{array}$ & $\begin{array}{c}-3728.76^{* * * *} \\
(872.14)\end{array}$ & $\begin{array}{c}-8.04 * * * \\
(1.38)\end{array}$ & $\begin{array}{c}-0.23 * * * \\
(0.03)\end{array}$ & $\begin{array}{l}-3.06 \\
(6.10)\end{array}$ \\
\hline 7 & $\begin{array}{c}-3561.94 * * * \\
(992.92)\end{array}$ & $\begin{array}{c}-6.80 * * * \\
(1.71)\end{array}$ & $\begin{array}{c}-0.18 * * * \\
(0.03)\end{array}$ & $\begin{array}{l}-3.42 \\
(7.16)\end{array}$ & $\begin{array}{c}-3250.53^{* * *} \\
(919.99)\end{array}$ & $\begin{array}{c}-7.38 * * * \\
(1.42)\end{array}$ & $\begin{array}{c}-0.20 * * * \\
(0.03)\end{array}$ & $\begin{array}{l}-2.06 \\
(6.54)\end{array}$ \\
\hline 8 & $\begin{array}{c}-3236.86 * * * \\
(1060.86)\end{array}$ & $\begin{array}{c}-7.54 * * * \\
(1.86)\end{array}$ & $\begin{array}{c}-0.19 * * * \\
(0.04)\end{array}$ & $\begin{array}{l}-0.63 \\
(6.86)\end{array}$ & $\begin{array}{c}-3070.94 * * * \\
(948.96)\end{array}$ & $\begin{array}{c}-6.88^{* * *} \\
(1.53)\end{array}$ & $\begin{array}{c}-0.22 * * * \\
(0.03)\end{array}$ & $\begin{array}{l}-2.82 \\
(6.83)\end{array}$ \\
\hline 9 & $\begin{array}{c}-3395.49 * * * \\
(1095.02)\end{array}$ & $\begin{array}{c}-7.40 * * * \\
(1.99)\end{array}$ & $\begin{array}{c}-0.19 * * * \\
(0.04)\end{array}$ & $\begin{array}{l}-8.76 \\
(6.89)\end{array}$ & $\begin{array}{c}-2866.97 * * * \\
(1044.53)\end{array}$ & $\begin{array}{c}-6.81 * * * \\
(1.63)\end{array}$ & $\begin{array}{c}-0.21 * * * \\
(0.03)\end{array}$ & $\begin{array}{c}-4.52 \\
(7.18)\end{array}$ \\
\hline 10 & $\begin{array}{l}-2309.60^{*} \\
(1234.77)\end{array}$ & $\begin{array}{c}-5.49 * * * \\
(2.01)\end{array}$ & $\begin{array}{c}-0.15 * * * \\
(0.04)\end{array}$ & $\begin{array}{l}-6.02 \\
(7.78)\end{array}$ & $\begin{array}{l}-1523.76 \\
(1096.65)\end{array}$ & $\begin{array}{c}-5.04 * * * \\
(1.65)\end{array}$ & $\begin{array}{c}-0.20 * * * \\
(0.03)\end{array}$ & $\begin{array}{c}1.88 \\
(7.31)\end{array}$ \\
\hline 11 & $\begin{array}{c}-3468.86 * * * \\
(1285.42)\end{array}$ & $\begin{array}{l}-4.08^{*} \\
(2.13)\end{array}$ & $\begin{array}{c}-0.17 * * * \\
(0.04)\end{array}$ & $\begin{array}{l}-11.93 \\
(7.90)\end{array}$ & $\begin{array}{c}-2662.45^{* *} \\
(1212.74)\end{array}$ & $\begin{array}{c}-4.14 * * * \\
(1.72)\end{array}$ & $\begin{array}{c}-0.22 * * * \\
(0.04)\end{array}$ & $\begin{array}{l}-5.49 \\
(8.33)\end{array}$ \\
\hline 12 & $\begin{array}{c}-3290.72 * * * \\
(1320.49)\end{array}$ & $\begin{array}{c}-4.53^{* *} \\
(2.23)\end{array}$ & $\begin{array}{c}-0.18^{* * *} \\
(0.05)\end{array}$ & $\begin{array}{l}-12.28 \\
(8.52)\end{array}$ & $\begin{array}{l}-2385.81 * \\
(1336.05)\end{array}$ & $\begin{array}{c}-4.14^{* *} \\
(1.81)\end{array}$ & $\begin{array}{c}-0.22 * * * \\
(0.04)\end{array}$ & $\begin{array}{l}-1.83 \\
(9.27)\end{array}$ \\
\hline 13 & $\begin{array}{c}-4025.35 * * * \\
(1318.37)\end{array}$ & $\begin{array}{c}-6.17 * * * \\
(2.52)\end{array}$ & $\begin{array}{c}-0.16^{* * *} \\
(0.05)\end{array}$ & $\begin{array}{l}-9.72 \\
(8.44)\end{array}$ & $\begin{array}{c}-3895.87 * * * \\
(1612.86)\end{array}$ & $\begin{array}{c}-5.21 * * * \\
(2.00)\end{array}$ & $\begin{array}{c}-0.22 * * * \\
(0.04)\end{array}$ & $\begin{array}{c}-8.36 \\
(11.85)\end{array}$ \\
\hline 14 & $\begin{array}{c}-4332.74 * * * \\
(1347.61)\end{array}$ & $\begin{array}{c}-5.54 * * \\
(2.62)\end{array}$ & $\begin{array}{c}-0.18 * * * \\
(0.05)\end{array}$ & $\begin{array}{c}-4.25 \\
(7.90)\end{array}$ & $\begin{array}{c}-4141.89 * * * \\
(1733.12)\end{array}$ & $\begin{array}{l}-3.89 * \\
(2.11)\end{array}$ & $\begin{array}{c}-0.20 * * * \\
(0.04)\end{array}$ & $\begin{array}{c}-13.28 \\
(12.84)\end{array}$ \\
\hline 15 & $\begin{array}{c}-3811.09 * * * \\
(1528.04)\end{array}$ & $\begin{array}{c}-7.81 * * * \\
(3.22)\end{array}$ & $\begin{array}{c}-0.17 * * * \\
(0.06)\end{array}$ & $\begin{array}{l}4.57 \\
(11.97)\end{array}$ & $\begin{array}{c}-4664.01 * * \\
(2066.79)\end{array}$ & $\begin{array}{l}-4.23^{*} \\
(2.56)\end{array}$ & $\begin{array}{c}-0.20 * * * \\
(0.05)\end{array}$ & $\begin{array}{c}-18.90 \\
(16.64)\end{array}$ \\
\hline 16 & $\begin{array}{l}-3016.26 \\
(1980.02) \\
\end{array}$ & $\begin{array}{c}-8.79 * * \\
(3.89) \\
\end{array}$ & $\begin{array}{c}-0.20 * * * \\
(0.08) \\
\end{array}$ & $\begin{array}{c}14.92 \\
(11.74) \\
\end{array}$ & $\begin{array}{c}-2512.94 \\
(1644.47) \\
\end{array}$ & $\begin{array}{l}-5.96^{*} \\
(3.22) \\
\end{array}$ & $\begin{array}{c}-0.21^{* * *} \\
(0.06) \\
\end{array}$ & $\begin{array}{c}-5.38 \\
(12.86) \\
\end{array}$ \\
\hline
\end{tabular}

Notes: Corrected standard errors in parentheses. * significant at $10 \%$; ** significant at $5 \%$; *** significant at $1 \%$. 
Table 5: Robustness check: informal employment proxied by non-receipt of fringe benefits 1, 2, and 3

\begin{tabular}{|c|c|c|}
\hline $\begin{array}{l}\text { Quarters before / } \\
\text { after }\end{array}$ & Fixed effect & Matching \\
\hline bef_D_4 & $\begin{array}{c}0.068 * * \\
(0.034)\end{array}$ & $\begin{array}{c}0.07 * * * \\
(0.03)\end{array}$ \\
\hline bef_D_3 & $\begin{array}{l}0.066^{*} \\
(0.034)\end{array}$ & $\begin{array}{c}0.09 * * * \\
(0.03)\end{array}$ \\
\hline bef_D_2 & $\begin{array}{l}0.070 * * \\
(0.034)\end{array}$ & $\begin{array}{c}0.09 * * * \\
(0.03)\end{array}$ \\
\hline bef_D_1 & $\begin{array}{c}0.069 * * \\
(0.035)\end{array}$ & $\begin{array}{c}0.09 * * * \\
(0.03)\end{array}$ \\
\hline bef_D_0 & $\begin{array}{c}0.113 * * * \\
(0.041)\end{array}$ & $\begin{array}{c}0.13^{* * *} \\
(0.04)\end{array}$ \\
\hline aft_D_1 & $\begin{array}{c}0.139 * * * \\
(0.043)\end{array}$ & $\begin{array}{c}0.15^{* * * *} \\
(0.04)\end{array}$ \\
\hline aft_D_2 & $\begin{array}{c}0.146^{* * * *} \\
(0.042)\end{array}$ & $\begin{array}{c}0.13^{* * * *} \\
(0.04)\end{array}$ \\
\hline aft_D_3 & $\begin{array}{c}0.134 * * * \\
(0.043)\end{array}$ & $\begin{array}{c}0.13^{* * *} \\
(0.04)\end{array}$ \\
\hline aft_D_4 & $\begin{array}{c}0.128 * * * \\
(0.043)\end{array}$ & $\begin{array}{c}0.12 * * * \\
(0.04)\end{array}$ \\
\hline aft_D_5 & $\begin{array}{c}0.140 * * * \\
(0.044)\end{array}$ & $\begin{array}{c}0.14^{* * * *} \\
(0.04)\end{array}$ \\
\hline aft_D_6 & $\begin{array}{c}0.136 * * * \\
(0.045)\end{array}$ & $\begin{array}{c}0.12 * * * \\
(0.04)\end{array}$ \\
\hline aft_D_7 & $\begin{array}{c}0.125 * * * \\
(0.044)\end{array}$ & $\begin{array}{c}0.10^{* * * *} \\
(0.04)\end{array}$ \\
\hline aft_D_8 & $\begin{array}{c}0.118 * * * \\
(0.044)\end{array}$ & $\begin{array}{c}0.07 \\
(0.04)\end{array}$ \\
\hline aft_D_9 & $\begin{array}{l}0.114^{* *} \\
(0.045)\end{array}$ & $\begin{array}{c}0.10^{* *} \\
(0.04)\end{array}$ \\
\hline aft_D_10 & $\begin{array}{c}0.117 * * * \\
(0.045)\end{array}$ & $\begin{array}{c}0.13^{* * * *} \\
(0.04)\end{array}$ \\
\hline aft_D_11 & $\begin{array}{c}0.130 * * * \\
(0.046)\end{array}$ & $\begin{array}{c}0.13^{* * *} \\
(0.05)\end{array}$ \\
\hline aft_D_12 & $\begin{array}{c}0.131 * * * \\
(0.047)\end{array}$ & $\begin{array}{l}0.10^{*} \\
(0.05)\end{array}$ \\
\hline aft_D_13 & $\begin{array}{c}0.140 * * * \\
(0.047)\end{array}$ & $\begin{array}{c}0.09 \\
(0.06)\end{array}$ \\
\hline aft_D_14 & $\begin{array}{l}0.124^{* *} \\
(0.048)\end{array}$ & $\begin{array}{c}0.07 \\
(0.06)\end{array}$ \\
\hline aft_D_15 & $\begin{array}{l}0.122 * * \\
(0.052)\end{array}$ & $\begin{array}{l}0.13^{*} \\
(0.07)\end{array}$ \\
\hline aft_D_16 & $\begin{array}{l}0.108^{*} \\
(0.060)\end{array}$ & $\begin{array}{c}0.08 \\
(0.08)\end{array}$ \\
\hline Constant & $\begin{array}{c}0.116^{* * *} \\
(0.003)\end{array}$ & \\
\hline Observations & 80067 & \\
\hline R-squared & 0.01 & \\
\hline
\end{tabular}




\section{APPENDIX}

Table A1. Selected key economic indicators for Russia.

\begin{tabular}{|c|c|c|c|c|c|c|c|c|c|c|c|c|c|c|c|c|c|c|c|c|}
\hline & 1989 & 1990 & 1991 & 1992 & 1993 & 1994 & 1995 & 1996 & 1997 & 1998 & 1999 & 2000 & 2001 & 2002 & 2003 & 2004 & 2005 & 2006 & 2007 & 2008 \\
\hline GDP per capita (2000 US\$) & 2693 & 2602 & 2465 & 2106 & 1926 & 1686 & 1618 & 1564 & 1591 & 1511 & 1614 & 1775 & 1870 & 1968 & 2122 & 2286 & 2444 & 2637 & 2868 & 3030 \\
\hline GDP growth rate, \% & & -3.0 & -5.0 & -14.5 & -8.7 & -12.6 & -4.1 & -3.6 & 1.4 & -5.3 & 6.4 & 10.0 & 5.1 & 4.7 & 7.3 & 7.2 & 6.4 & 7.7 & 8.1 & 5.6 \\
\hline GDP as \% of GDP 1989 & 100.0 & 97.0 & 92.1 & 78.7 & 71.9 & 62.7 & 60.2 & 58.0 & 58.8 & 55.7 & 59.3 & 65.2 & 68.5 & 71.7 & 77.0 & 82.5 & 87.8 & 94.6 & 102.2 & 107.9 \\
\hline Employment ratio, \% & 83.6 & 83.4 & 81.7 & 78.6 & 75.5 & 70.9 & 69.6 & 68.2 & 65.1 & 63.0 & 67.7 & 69.9 & 69.6 & 70.7 & 69.7 & 69.8 & 70.3 & 70.9 & 72.8 & 73.6 \\
\hline Employment in industry & & & & & & & 34.0 & 32.5 & 30.0 & 29.1 & 28.2 & 28.4 & 29.4 & 29.5 & 30.4 & 29.7 & 29.8 & 29.3 & 29.2 & 28.9 \\
\hline Employment in agriculture & & & & & & & 15.7 & 15.3 & 12.2 & 11.7 & 15.0 & 14.5 & 12.0 & 11.3 & 10.9 & 10.2 & 10.2 & 10.0 & 9.0 & 8.6 \\
\hline ILO unemployment rate, \% & & & & 5.2 & 5.9 & 8.1 & 9.4 & 9.7 & 11.8 & 13.3 & 13.0 & 10.6 & 9.0 & 7.9 & 8.2 & 7.8 & 7.2 & 7.2 & 6.1 & 6.3 \\
\hline $\begin{array}{l}\text { Long-term unemployment } \\
\text { incidence, \% }\end{array}$ & & & & 12.2 & 15.2 & 23.1 & 29.7 & 32.8 & 38.1 & 41.0 & 47.2 & 42.3 & 36.9 & 39.2 & 37.6 & 39.0 & 38.5 & 41.7 & 38.9 & 33.3 \\
\hline Youth unemployment rate, \% & & & & 13.0 & 13.5 & 16.3 & 18.8 & 19.3 & 23.5 & 27.1 & 23.9 & 20.7 & 18.0 & 15.6 & 17.5 & 17.2 & 15.7 & 16.5 & 14.7 & 14.1 \\
\hline Gini coefficient (earnings) & 0.271 & 0.269 & 0.325 & 0.371 & 0.461 & 0.446 & 0.471 & 0.483 & & & & & 0.521 & 0.491 & & 0.469 & 0.445 & 0.451 & 0.439 & 0.423 \\
\hline Real wages growth rate, \% & & & -3.4 & -32.7 & 0.4 & -7.9 & -28.0 & 6.0 & 4.7 & -13.0 & -22.0 & 21.0 & 20.0 & 16.0 & 10.9 & 10.6 & 12.6 & 13.3 & 17.2 & 11.5 \\
\hline
\end{tabular}


Table A2. Reasons for leaving job and classification as quit or displacement

\begin{tabular}{lc}
\hline \hline REASON & CLASSIFICATION \\
\hline 1 Closing down of enterprise/organization & Displacement \\
2 Moving of enterprise/organization & Displacement \\
3Reorganization of enterprise/organization & Displacement \\
4 Bankruptcy of enterprise/organization & Displacement \\
5 Privatization of enterprise/organization & Displacement \\
6 Dismissal initiated by employer & Displacement \\
7 Personnel reduction & Displacement \\
8 Expiring of employment contract & Quit \\
9 Expiring of probation time & Quit \\
10 Military service & Quit \\
11 Imprisonment & Quit \\
12 Own illness or injury & Quit \\
13 Studies & Quit \\
14 Retirement & Quit \\
15 Early retirement & Quit \\
16 Marriage & Quit \\
17 Parental leave & Quit \\
18 Need to take care of other members of family & Quit \\
19 Change of residence & Quit \\
20 Wanted/was proposed higher salary & Quit \\
21 Wanted/was proposed better working conditions & Quit \\
22 Wanted/was proposed more interesting work & Quit \\
24 Wanted to start own business & Quit \\
25 End of farming/sole proprietorship & Quit \\
\hline & Quit \\
& Variable \\
\hline
\end{tabular}




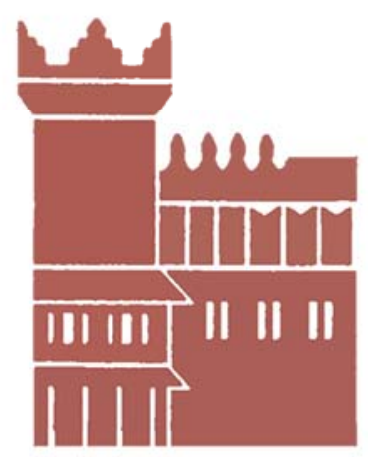

Alma Mater Studiorum - Università di Bologna DEPARTMENT OF ECONOMICS

Strada Maggiore 45

40125 Bologna - Italy

Tel. +39051 2092604

Fax +390512092664

http://www.dse.unibo.it 